Universidad de Lima

Escuela de Posgrado

Maestría en Derecho Empresarial

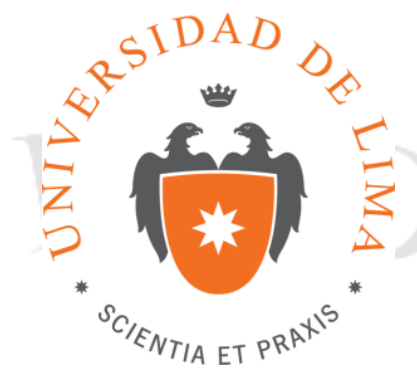

\title{
CONCEPTO, CONTENIDO Y \\ FORMALIDADES DEL CONVENIO \\ ARBITRAL
}

Tesis para optar el Grado Académico de Maestro en Derecho Empresarial

\section{Laura Castro Zapata}

Código 20031570

Asesor: Oswaldo Hundskopf Exebio

Lima - Perú

Noviembre del 2012 


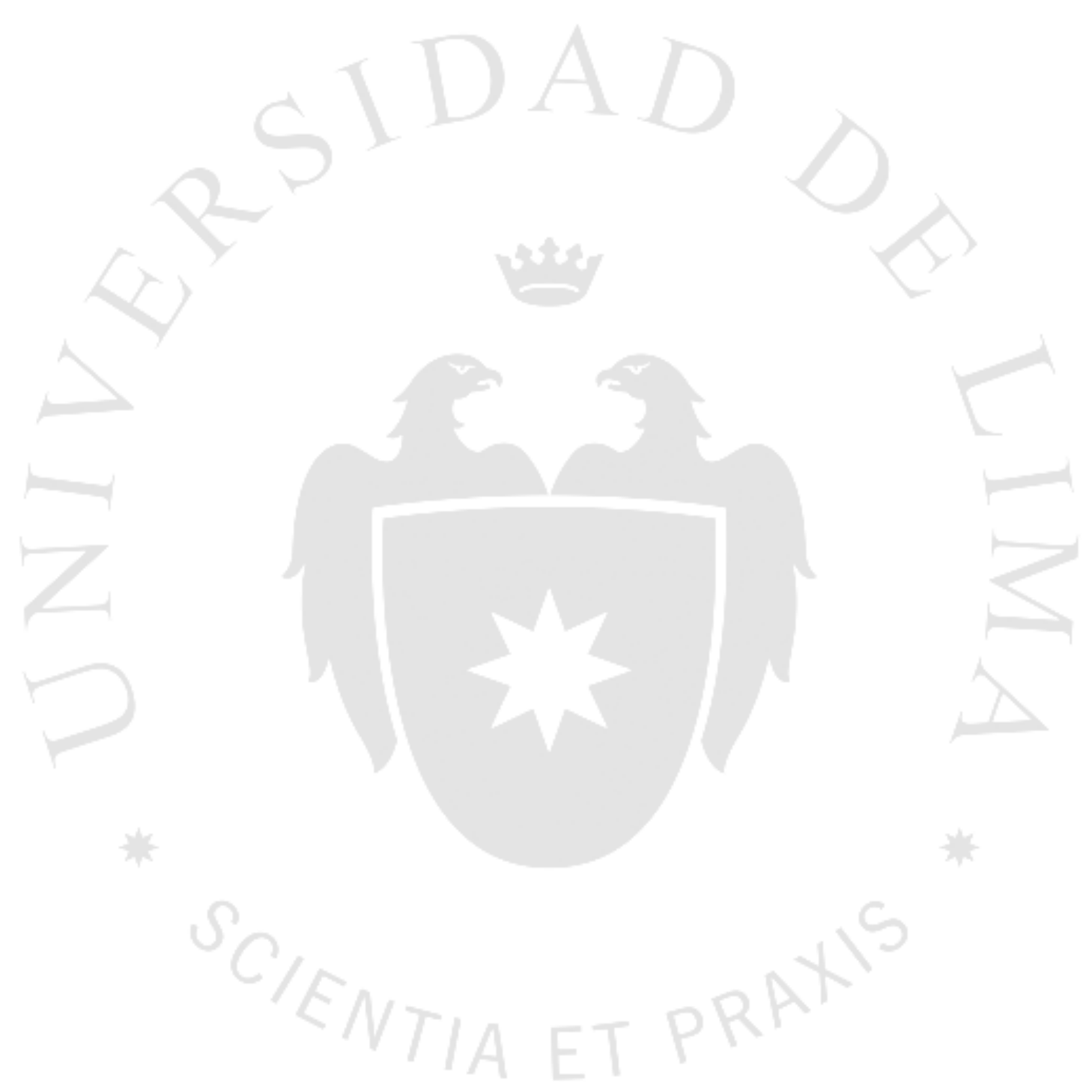

ii 
CONCEPTO, CONTENIDO Y

FORMALIDADES DEL CONVENIO

ARBITRAL 


\section{TABLA DE CONTENIDO}

\section{INTRODUCCIÓN}

1

CAPÍTULO I: EL CONVENIO ARBITRAL .................................................................2

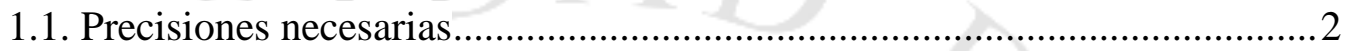

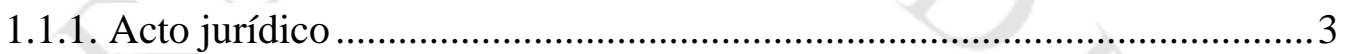

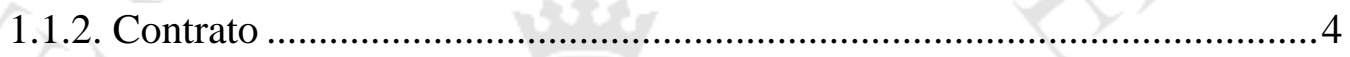

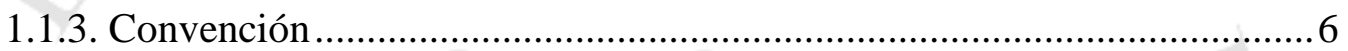

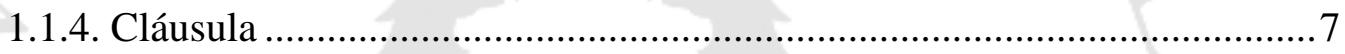

1.2. Naturaleza jurídica del convenio arbitral.............................................. 8

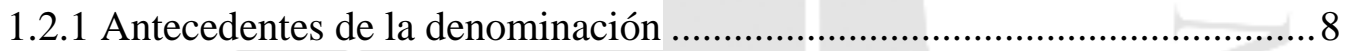

1.2.2. ¿Puede la cláusula compromisoria dar origen al arbitraje? .................... 10

1.2.2.1.La cláusula compromisoria no da origen al arbitraje ......................... 10

1.2.2.2. La cláusula compromisoria sí da origen al arbitraje............................. 13

1.2.3. Teorías sobre la naturaleza jurídica del convenio arbitral ...................... 14

1.2.3.1. El convenio arbitral reviste la naturaleza jurídica de convenio............ 14

1.2.3.2. El convenio arbitral reviste la naturaleza jurídica de un acto jurídico .16

1.2.3.3. El convenio arbitral reviste la naturaleza jurídica de una convención . 16

1.2.3.4. El convenio arbitral reviste la naturaleza jurídica de un acuerdo......... 17

1.2.3.5. El convenio arbitral reviste la naturaleza jurídica de un contrato ........ 19

1.2.4. El convenio arbitral entendido como contrato diferente e independiente

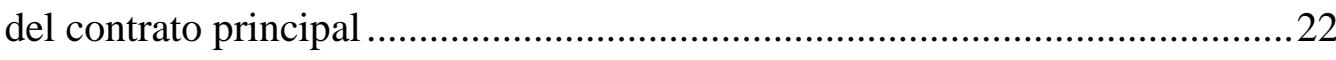

1.2.5. La posición del legislador nacional ....................................................24 
1.2.6. La posición de la legislación extranjera .............................................26

CAPÍTULO II: CLASIFICACIÓN DEL CONVENIO ARBITRAL ........................29

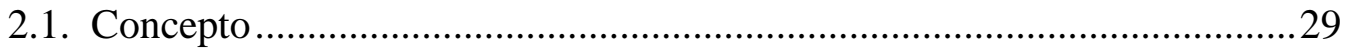

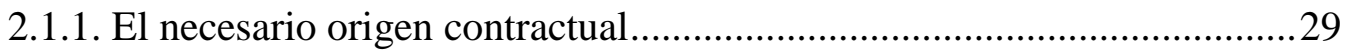

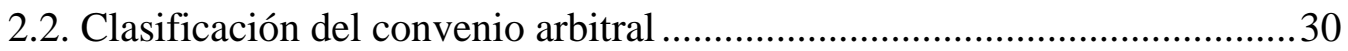

2.2.1. Según el momento en que se pacta ..................................................... 30

2.2.2. Según si constituye una cláusula contractual o un contrato independiente 31

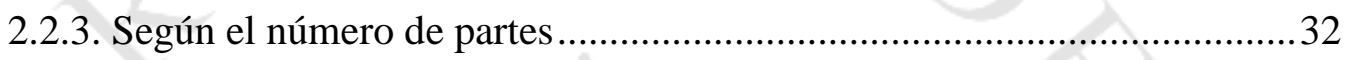

2.2.4. Según a quiénes comprende sus efectos .............................................. 34

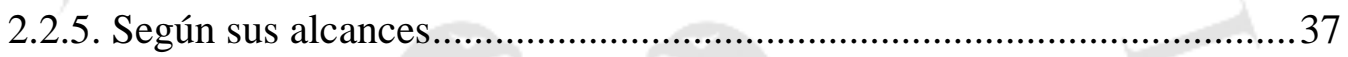

2.2.6. Según exista o no negociación previa del convenio arbitral ...................40

2.2.7. Por el tipo de arbitraje que contempla ............................................... 41

2.2.8. Según contemple o no un arbitraje institucional ................................... 41

2.2.9. Según si el convenio arbitral contempla un plazo o no ........................ 42

2.2.10. Según se contemple o no el número de árbitros ..................................43

2.2.11. Según si el convenio arbitral contempla o no el idioma en el que se desarrollará el arbitraje ...................................................................... 45

2.2.12. Según si el convenio contempla o no la manera de elegir a los árbitros46

2.2.13. Según si el convenio establece o no los requisitos que deben reunir los árbitros

2.2.14. Según si el convenio establece o no criterios para los honorarios del tribunal arbitral

2.2.15. Según si el convenio arbitral establece o no cuál de las partes debe asumir el pago de los costos del arbitraje

2.2.16. Según si el convenio arbitral establece o no la sede del arbitraje. 


\section{CAPÍTULO III: COMENTARIOS SOBRE LA FORMALIDAD DEL}

CONVENIO ARBITRAL ........................................................................................55

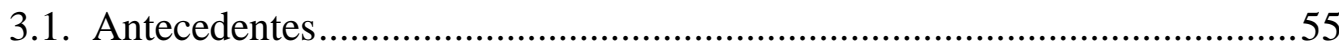

3.2. La formalidad del convenio arbitral en el Decreto Legislativo n. ${ }^{\circ} 1071$...56

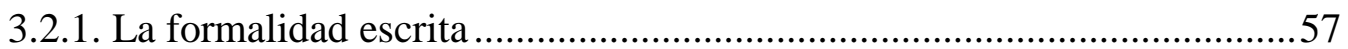

3.2.2. Ejecución contractual asimilada a la formalidad escrita .......................58

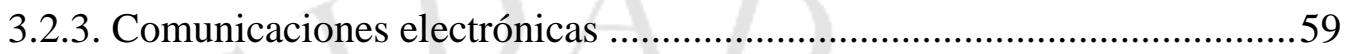

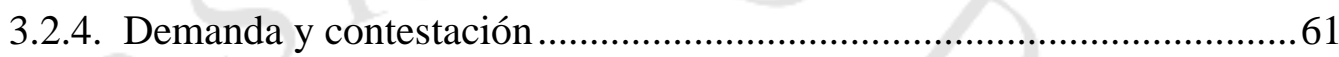

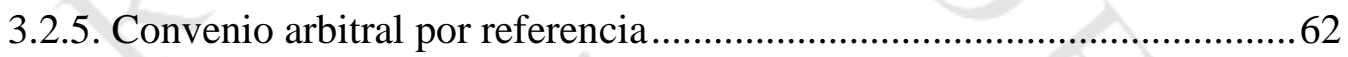

3.2.6. Convenio arbitral en arbitraje internacional ........................................63

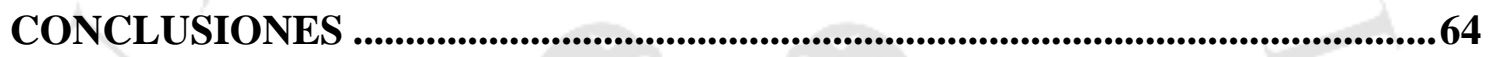




\section{INTRODUCCIÓN}

No cabe duda de que, independientemente de la base constitucional que en el caso peruano tiene la jurisdicción arbitral, y que representa el fundamento y fuerza de la misma existencia del arbitraje en nuestro país, es el convenio arbitral el pacto que, en concreto, da vida al arbitraje.

En ese sentido, el convenio arbitral constituye una pieza fundamental dentro del esquema de cualquier arbitraje.

Se podría decir, incluso, que representa la piedra angular del arbitraje, en la medida de que, sin su existencia, no existiría proceso arbitral alguno.

Dentro de tal orden de ideas, el objeto del presente estudio consistirá en analizar a profundidad los alcances del convenio arbitral dentro del marco de la legislación nacional.

Queremos dejar sentado que, cuando nos referimos a «legislación nacional» lo estamos haciendo en el sentido más amplio de la palabra. Nuestro análisis no se va a circunscribir a lo dispuesto por el Decreto Legislativo n. ${ }^{\circ} 1071$, en adelante, la Ley de Arbitraje, sino a lo establecido por la legislación peruana en su conjunto, vale decir, incluyendo a los aspectos relevantes de la legislación civil y de la relativa a la contratación pública.

Dentro de tal orden de ideas, el trabajo se dividirá en tres capítulos. En el primero de ellos, estudiaremos lo relativo al convenio arbitral; en el segundo, las diferentes clasificaciones que se pueden hacer de él, desde diferentes ópticas o perspectivas; en tanto que en el tercero estudiaremos un tema que, tanto por su tratamiento legislativo, como por la riqueza conceptual que contiene, amerita ser analizado a profundidad, ya que de él se pueden extraer, no sólo conclusiones importantes sobre el presente, sino también algunas otras sobre las perspectivas que tendrá en el futuro la formalidad del convenio arbitral.

Pasamos, entonces, al análisis de tales temas, los mismos que sometemos a consideración de quienes lean páginas. 


\section{CAPÍTULO I: EL CONVENIO ARBITRAL}

Hoy por hoy, algunas de las principales tareas que el Estado debe cumplir vienen siendo asumidas por particulares. Por ejemplo, el monopolio que hasta hace algunos años tenía el Estado para administrar justicia está desapareciendo poco a poco, y nuevas formas de resolución de conflictos han emergido y cobrado cada vez mayor importancia.

Entre las muchas explicaciones que al respecto se dan para explicar este fenómeno - es decir, para que el Estado no sea más quien realice determinada actividad-, está siempre presente el tema de la corrupción y la celeridad.

Pues bien, hasta el siglo pasado, y sólo por citar un ejemplo, el Estado tenía como principal función la de actuar como un ente que participara de manera activa en la vida económica como empresa. Ahora ello quedó atrás y el Estado, en lo que a la actividad empresarial se refiere, tiene como única tarea la de ser un organismo subsidiario y regulador de dicha actividad, fomentándola y otorgándole un marco normativo acorde a las necesidades que el presente y el futuro exigen.

El tema de la administración de justicia no pudo ser ajeno a este fenómeno, y hoy en día tenemos, entre otras figuras, al arbitraje, el cual, como mecanismo alternativo de resolución de conflictos, cobra cada vez mayor utilidad.

Sin embargo, y sin perjuicio de lo expresado, creemos preciso realizar algunos deslindes conceptuales para poder abordar con mayor pulcritud el tema bajo análisis.

\subsection{Precisiones necesarias}

Antes de abordar el problema que suscita la naturaleza jurídica del convenio arbitral, resulta necesario que tengamos presente qué es lo que significan los conceptos que tratan de hacer suya esta figura jurídica. Así, tenemos el acto jurídico, el contrato y, finalmente, el convenio.

En adelante, el concepto de cada uno de ellos. 


\subsubsection{Acto jurídico}

Según el artículo 140 del Código Civil peruano de 1984, el acto jurídico es la manifestación de la voluntad destinada a crear, regular, modificar o extinguir relaciones jurídicas.

Sin embargo, y al margen de que autorizada doctrina nacional ${ }^{1}$ postula la corriente de tratar de abandonar la clásica concepción francesa del acto jurídico, consideramos necesario esclarecer algunos conceptos preliminares sobre el particular.

Vidal Ramírez, ${ }^{2}$ conceptúa el acto jurídico como: "Un acto jurídico, voluntario, licito, como manifestación de la voluntad y efectos queridos que respondan a la intención del sujeto, de conformidad con el derecho objetivo."

Por otra parte, es evidente también que los actos jurídicos pueden revestir carácter unilateral o plurilateral. Así, serán actos jurídicos unilaterales aquéllos para cuya celebración solamente se requiere de la manifestación de voluntad de un agente, vale decir, de una parte. Por ejemplo, el testamento, el mismo que en el Perú sólo puede celebrarse de manera unilateral, en la medida de que se encuentran prohibidos los testamentos conjuntos.

De otro lado, tenemos a los actos jurídicos plurilaterales, en la práctica mucho más numerosos que los unilaterales, y son aquéllos para cuya celebración se requiere la concurrencia del acuerdo de dos o más voluntades, declaradas por las respectivas partes que les dan nacimiento. Por ejemplo, el matrimonio, que de conformidad a lo dispuesto por el artículo 234 del Código Civil, es la unión voluntariamente concretada por un varón y una mujer legalmente aptos para ella y formalizada con sujeción a las disposiciones de dicho Código, a fin de hacer vida común.

Ahora bien, hechas estas precisiones de carácter teórico, resulta necesario señalar que los contratos constituyen una especie de los actos jurídicos, en la medida de que, por un lado, si el universo de dichos actos incluye tanto a aquéllos de carácter unilateral como aquellos otros de carácter plurilateral, los contratos se ubican única y

\footnotetext{
${ }^{1}$ Para mayor información, consultar la obra del profesor Lizardo Taboada (Taboada Córdova, Lizardo. Acto jurídico, negocio jurídico y contrato. Lima: Grijley, 2002, pp. 43 y ss.).

${ }^{2}$ Vidal Ramírez, Fernando. El acto jurídico. Lima: Gaceta Jurídica, 2007, 7. a ed., p. 38. Dentro de esta misma línea de pensamiento, encontraremos a José León Barandiarán (León Barandiarán, José. Acto jurídico. Lima: Gaceta Jurídica, 1997, pp. 37 y ss.).
} 
exclusivamente dentro de los actos jurídicos plurilaterales. Además, si tenemos en consideración que algunos actos jurídicos pueden revestir, fundamentalmente, contenido patrimonial y otros carecer de dicho contenido, los contratos forman parte de ese grupo de actos jurídicos que tienen contenido de orden patrimonial. Así las cosas, podemos afirmar que los contratos son, obviamente, actos jurídicos.

\subsubsection{Contrato}

Conforme a lo estipulado por el artículo 1351 del Código Civil peruano, el contrato es el acuerdo de dos o más partes para crear, regular, modificar o extinguir una relación jurídica patrimonial.

De esta definición se deben extraer una serie de consideraciones que, a nuestro juicio, resultan indispensables.

Así, las cuatro funciones que cumplen los contratos serían las siguientes:

En primer lugar, cuando se habla de la creación de obligaciones, la ley se está refiriendo al nacimiento de las mismas. Se sabe que los contratos son fuentes generadoras por excelencia de obligaciones, constituyendo — junto con la ley — la fuente más numerosa de las mismas. Cuando hablamos de un contrato creador de obligaciones, estamos haciendo alusión a aquellos actos que generan obligaciones que antes no existían; vale decir, que no versan sobre relaciones jurídicas que preexistan a la celebración de dicho acto. Ejemplo de lo señalado, lo constituyen la compraventa, la permuta, el arrendamiento, el suministro, la donación, el mutuo, etc., sólo por citar algunos de los contratos típicos más representativos que se encuentran regulados en nuestro país.

De otro lado, al hablar de contratos regulatorios, lo estamos haciendo con relación a aquéllos cuyas disposiciones tienden a llenar un vacío respecto de algún contrato preexistente; vale decir, de contratos en los que se tienda a especificar o detallar algunos aspectos no contemplados en contratos anteriores.

En tercer lugar, tenemos a los contratos modificatorios, cuya función es la de modificar obligaciones convenidas por las propias partes con anterioridad, comprendiéndose, tanto aquellos casos en los cuales las partes convinieron expresamente algo y aquellos otros casos en los cuales la ausencia de pacto expreso fue 
cubierta por la aplicación supletoria de una norma de carácter dispositivo.

Finalmente, se tiene a los contratos de carácter extintivo, cuya finalidad es poner término a obligaciones preexistentes y cuyo cumplimiento se encontraba pendiente. Así, el caso más representativo sería el del mutuo disenso o resolución convencional, por el cual las partes que han celebrado un acto jurídico, acuerdan dejarlo sin efecto (argumento del artículo 1313 del Código Civil peruano).

De acuerdo al concepto de contrato adoptado por el artículo 1351 del Código Civil, resulta evidente que el objeto de todo contrato será, necesariamente, la creación, modificación, regulación o extinción de obligaciones. En tal sentido, las obligaciones, para tales efectos, deben tener por objeto una o más prestaciones de contenido netamente patrimonial.

La patrimonialidad de la obligación se refiere única y exclusivamente al hecho de poder valorizarla, sin contravenir disposición legal alguna, así como tampoco transgredir los valores morales, cívicos, patrióticos, o de otra índole, que imperen en un determinado momento. En tal sentido, existirán determinados deberes jurídicos cuyo cumplimiento está prescrito por la ley, pero que no resulta posible valorizar. Un ejemplo representativo está constituido por los deberes jurídicos de fidelidad y cohabitación nacidos del matrimonio.(Osterling Parodi y Castillo Freyre, 2008, p. 93104)

Sin embargo, y sin lugar a dudas, siempre estará latente la posibilidad de que en el futuro cambien los valores éticos y morales de la propia sociedad, la misma que podría llegar a considerar susceptibles de apreciación patrimonial los deberes jurídicos a que hemos hecho referencia.

Por otra parte, cuando se celebra un contrato se genera entre las partes la denominada relación jurídica patrimonial.

En el Perú, los contratos tienen efectos meramente obligacionales. Esto significa que los contratos no transfieren, por sí mismos, ningún derecho real. Todos los contratos generan, modifican, regulan o extinguen obligaciones, pero por sí mismos no transfieren derechos.

Es claro que en los contratos con prestaciones recíprocas, las partes tendrán intereses opuestos, vale decir que cada centro de interés buscará obtener determinados resultados que se contraponen a aquéllos buscados por la parte contraria. En ese 
sentido, las partes, al celebrar un contrato, tratarán de salvaguardar sus intereses buscando obtener la mayor seguridad posible. Así, en la compraventa, el vendedor busca obtener una cantidad de dinero, llamada precio, de la otra parte denominada comprador; y, a su vez, el comprador pretende obtener la propiedad del bien y no una cantidad de dinero.

\subsubsection{Convención}

Como ya se dijo, el contrato es el acuerdo de voluntades destinado a crear, regular, modificar o extinguir obligaciones.

Por su parte, Cabanellas (1989), señala que es: «El concierto de voluntades, expresado en convención, pacto, contrato, tratado o ajuste».(p. 365)

Sin embargo, esta definición no nos es útil para efectos de desarrollar la presente investigación.

Así las cosas, hoy en día es claro que el contrato tiene esa función de carácter múltiple (función creadora, reguladora, modificadora o extintiva); pero ello no siempre fue así, ya que en el antiguo Derecho francés se consideraba al contrato única y exclusivamente como un acto creador de obligaciones, de manera tal que la regulación, modificación o extinción de las mismas no podría producirse a través del contrato, sino a través de una figura distinta denominada convención. De lo que acabamos de mencionar se deduce claramente que el contrato era en el Derecho francés, una especie del género llamado convención. Esta distinción — la referida a contrato y convención, válida durante muchísimo tiempo, ha perdido toda vigencia, en la medida de que en la actualidad prima la aplicación teórica y práctica del concepto del contrato. ${ }^{3}$

Por su parte, Manuel de la Puente, respecto a esta distinción señala que ambos términos — convención y contrato- han sido ya diferenciados incluso por uno de los inspiradores del Code Napoléon, como es Pothier. ${ }^{4}$

\footnotetext{
${ }^{3}$ Dentro de esta misma línea de pensamiento, se pronuncia Manuel de la Puente (De la puente y Lavalle, Manuel. El contrato en general. Lima: Palestra Editores, 2002, pp. 63 y ss.).

${ }^{4}$ Decía Pothier que un contrato es una especie de convención, por lo cual para saber lo que es un contrato era antes necesario saber qué es una convención.

Según el mismo autor, una convención es el consentimiento de dos o más personas, para tomar entre ellas algún compromiso, para resolver uno existente, o para modificarlo, agregando que la especie de convención que tiene por objeto sólo formar algún compromiso, es lo que se llama contrato. La concepción de Pothier fue recogida por el artículo 1101 del Código Napoléon, según el cual el
} 
Ahora bien, de lo expresado, entendemos que la convención puede ser un acto jurídico bilateral o plurilateral, tenga o no contenido patrimonial. Dentro de ese orden de ideas, el contrato es también un acto jurídico bilateral o plurilateral, pero de contenido netamente patrimonial.

En conclusión, la convención sería el género y el contrato sería la especie. En ese entender, un típico ejemplo de convención vendría a ser el matrimonio, en tanto que un típico ejemplo de contrato vendría a ser la compraventa.

\subsubsection{Cláusula}

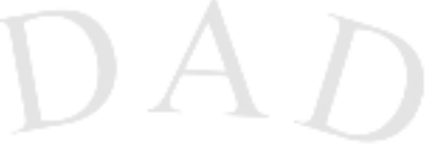

Cabanellas (1989, p. 161), al respecto nos dice que cláusula viene «del latín, claudere, cerrar, clausus, cerrado. Disposición particular que forma parte de un tratado, edicto, convención, testamento y cualquiera (sic) otro acto o instrumento público o privado. También se entiende por cláusula cada uno de los periodos de que constan los actos y

contrato es una convención por la cual una o más personas se obligan, hacia otras varias más, a dar, a hacer o a no hacer alguna cosa. De allí, esta concepción se difundió considerablemente en el siglo xix. Surgió así el criterio de que la convención es el género, en el sentido de que puede crear, modificar o extinguir cualquier relación jurídica y el contrato es la especie, pues sólo puede crear obligaciones (de dar, de hacer o de no hacer).

Por eso, dice Sánchez Román que contratar es siempre convenir, pero que convenir no es siempre contratar (este autor considera que las convenciones pueden ser jurídicas o no jurídicas, y que sólo las jurídicas son el género de la especie contrato). En la misma línea de pensamiento, Giorgi manifiesta que el contrato es el convenio jurídicamente eficaz para crear obligaciones, lo cual él considera lógico, pues si el contrato es una de las fuentes de las obligaciones, ¿cómo puede, sin rebelarse contra su significado natural, adaptarse a un convenio que modifica o disuelve una obligación?

Resulta así que, según esta concepción, para crear una obligación se requiere de un contrato, pero para modificarla o extinguirla es necesaria una convención, lo cual no tiene mucho sentido. Si un acto jurídico tiene la potencialidad suficiente para crear una obligación, o sea para darle existencia, no se percibe por qué debe carecer de un poder semejante para modificar o extinguir la que creó.

El hecho de que el contrato sea una fuente de las obligaciones no obtusa conceptualmente para que sea también un acto modificatorio o extintivo de las mismas, bien sea las que tienen origen contractual o bien, por acuerdo entre acreedor y deudor, las generadas por las otras fuentes de las obligaciones. En efecto, el contrato no crea otro contrato, ni modifica otro contrato, ni extingue otro contrato, sino lo que crea, modifica o extingue es una relación jurídica patrimonial, o sea la obligación, que, en el caso de la modificación y extinción, bien puede haber nacido de un contrato o bien de cualquier otro supuesto jurídico apto para generar obligaciones, siempre, desde luego, que la ley permita esta modificación o extinción.

Tales ideas han llevado a la doctrina moderna a considerar que el contrato cubre todo el Derecho de Obligaciones y que, por lo tanto, es apto tanto para crear como para modificar y extinguir obligaciones. Dicha tendencia doctrinal ha sido recogida por el Código Civil italiano de 1942, cuyo artículo 1321 establece que el contrato es el acuerdo de dos o más personas para constituir, regular o extinguir entre sí una relación jurídica patrimonial.

El Código Civil peruano copió, con ligeros cambios (se agregó la palabra "modificar" y suprimió la expresión entre sí), la fórmula italiana.

En estas condiciones, la convención sigue siendo el género, pues es el acuerdo entre varias personas destinado a crear, modificar o extinguir un vinculo jurídico cualquiera, el contrato la especie, ya que la creación, modificación o extinción sólo puede referirse a una relación jurídica patrimonial. 
contratos. Las cláusulas pueden ser establecidas libremente por las partes, con tal de que no se opongan a las leyes, a la moral o al orden público ni a lo sustancial de la convención o del acto. Aunque no se expresen en una y otro, las cláusulas de estilo (v.) se sobreentienden incluidas».

Es evidente que no ahondaremos más sobre el particular, pues no constituye propósito del presente trabajo realizar un extenso análisis sobre cada uno de los conceptos antes mencionados. Lo único que buscamos con este breve resumen es dar un panorama que permita al lector tener parámetros para comprender mejor el alcance de cada una de las teorías que más adelante desarrollaremos.

\subsection{Naturaleza jurídica del convenio arbitral}

Hoy en día, es usual que en la mayoría de contratos se incluya una cláusula de solución de conflictos o de controversias. Esta cláusula tiene diversas denominaciones. Y, así, en el Derecho anglosajón es conocida como Dispute Resolution, y a través de ésta se determina la vía por la cual se resolverá el o los conflictos que se deriven del contrato que la contiene, es decir si dicha solución se llevará a cabo a través de un proceso arbitral (fuero privado) o de un proceso ordinario (Poder Judicial).

Sin embargo, y antes de ver frente a qué supuesto nos encontramos, resulta importante conocer cuáles fueron los antecedentes legislativos sobre el particular en nuestro país, ya que, como bien se sabe, no podemos saber hacia dónde vamos sin antes saber de dónde venimos.

\subsubsection{Antecedentes de la denominación}

Cantuarias (2007), señala que el origen del convenio arbitral data del Código de Procedimientos Civiles de 1912, así como también estuvo presente en el Código Civil de 1984 (mientras estuvieron vigentes las disposiciones arbitrales en dicho cuerpo legal). (p. 201)

Así, la ley distingue dos tipos de contratos arbitrales: (i) la cláusula compromisoria y (ii) el compromiso arbitral. El primero suponía un contrato preparatorio que se suscribía con anterioridad a la existencia de la controversia. En él las partes reservaban la sumisión de sus futuras controversias al arbitraje. De otro lado, 
el segundo constituía un contrato definitivo que necesariamente tenía que otorgarse para acudir al arbitraje una vez que la controversia se dé y esté debidamente determinada. De esta manera, aun cuando las partes hubieran suscrito un contrato de cláusula compromisoria, cuando la controversia les era conocida, ellos debían otorgar un compromiso arbitral, como requisito necesario para activar la vía arbitral.

Por otra parte, a nivel de la legislación extranjera, ambas figuras — la cláusula compromisoria y el compromiso arbitral-, estuvieron presentes en la legislación de Latinoamérica.

Dentro de tal orden de ideas, cabría hacerse la interrogante, en el sentido de qué fue lo que sucedió, entonces, para que la legislación nacional y otras dejaran de lado esta división y adoptaran la denominación de convenio arbitral.

Para tal efecto, se debe tener en claro la distinción que en párrafos anteriores realizamos; a saber, que la cláusula compromisoria y el compromiso arbitral son cosas distintas.

Cabe señalar a estas alturas que dicha distinción con el tiempo desapareció porque en los hechos, para que el arbitraje cumpla con la finalidad para la cual había sido pactado (servir de vía alternativa para resolver los posibles conflictos), la misma constituía un obstáculo.

Ello, debido a que con la cláusula compromisoria las partes se obligan a someterse, en un futuro, a un proceso arbitral, es decir, las partes llegaban a un acuerdo estableciendo que para resolver algún conflicto que se suscite en el futuro se recurriría al arbitraje. Así, se entiende que en dicha cláusula no se ha concretado la celebración del arbitraje, sino que se ha celebrado un compromiso a contratar dicho arbitraje en un futuro. Por lo tanto, el compromiso vendría a ser, recién, el contrato definitivo con el que se genere el arbitraje.

En conclusión, respecto a esta primera parte, coincidimos plenamente con lo expresado por Castillo Freyre y Vásquez Kunze (2006) cuando señalan que:

Un contrato que no genera nunca por sí mismo arbitraje es el que en la doctrina se conoce como cláusula compromisoria, entonces, la esencia para entender lo que es la cláusula compromisoria está en saber que mediante ella nunca jamás se concierta o celebra un arbitraje. (p. 54, 55)

Así, pues — continuando con la misma línea de pensamiento de los autores citados—,lo 
que sucedía en la mayoría de casos era que, solicitado el cumplimiento de lo convenido en la cláusula compromisoria (esto es, la obligación de celebrar un arbitraje a través del compromiso), por una de las partes (obviamente la cumplidora), la otra se negaba a suscribirlo. Ante esta situación se acudía al Poder Judicial para que luego de un largo proceso, fuera el juez quien en rebeldía otorgara el compromiso arbitral. De esta manera por exigencia de este absurdo sistema, las partes terminaban, finalmente, en la vía judicial. Lo cual atentaba con la finalidad del arbitraje, es decir, el de ser una vía alterna para resolver controversias.

La postura establecida por Castillo y Vásquez es asumida también por García Calderón (2004), al indicar que la legislación anterior constituía un freno al desarrollo del arbitraje, debido a que hacía la división entre cláusula compromisoria y compromiso:

Dicha legislación constituía un freno al desarrollo del arbitraje nacional, ya que aquella parte que se negaba a celebrar el compromiso arbitral luego de haber celebrado el de cláusula compromisoria, debía ser emplazada judicialmente para el otorgamiento de este segundo contrato, lo que era perjudicial para el arbitraje al abordar antes de su nacimiento el procedimiento privado, supeditándolo al proceso judicial de formalización del compromiso arbitral. (p. 60)

Sin embargo, la división que existía entre estas dos figuras - la cláusula compromisoria y el compromiso-, no sólo constituía un impedimento para cumplir eficazmente la función del arbitraje, sino que además creaba incertidumbre en la doctrina, debido a que se discutía si la cláusula compromisoria era aquel acuerdo que daba inicio al arbitraje o, más bien, si el compromiso era el encargado de dar nacimiento al mismo.

\subsection{2. ¿Puede la cláusula compromisoria dar origen al arbitraje?}

Si bien es cierto, la problemática sobre la naturaleza jurídica del arbitraje es un tema aún no acabado, antiguamente se discutía si la cláusula compromisoria podía o no dar origen al arbitraje. Así, existen dos posiciones al respecto:

\subsubsection{La cláusula compromisoria no da origen al arbitraje}

Lohmann Luca de Tena (1988), comentando las normas del Código Civil en las que antiguamente se encontraban la cláusula compromisoria y el compromiso arbitral, 
rechaza que la cláusula compromisoria constituya el inicio o el origen por el que se da un arbitraje. En ese sentido, esboza una definición de la cláusula compromisoria, al señalar que:

La cláusula compromisoria es aquel convenio por el cual las partes obligan a someter a arbitraje todas o algunas discrepancias que en el futuro se susciten entre ellas derivadas de una relación jurídica y que puedan ser objeto de solución arbitral. (p. 79)

Asimismo — señala Lohmann-, el compromiso arbitral se define, según el artículo 1909 del Código Civil, ${ }^{5}$ como aquél por el cual «dos o más partes convienen que una controversia determinada, materia o no de un juicio, sea resuelta por tercero o terceros a quienes designa y a cuya jurisdicción y decisión se someten expresamente». ${ }^{6}$

En ese entender, la norma transcrita es clara y exacta, aunque acaso el nombre asignado al «convenio» («compromiso») no sea el más idóneo, pues comprometerse equivale a obligarse. Con lo cual, literalmente, podríamos traducir el compromiso como un contrato de obligación arbitral, lo que no deja de ser redundante, ya que un contrato constituye una fuente de obligaciones.

En una posición intermedia, Ulises Montoya $^{7}$ establece que la cláusula compromisoria puede dar nacimiento al arbitraje, aun cuando no es obligatorio que se pacte dicha cláusula, ya que el arbitraje puede nacer con la realización del compromiso arbitral. Sin embargo, aclara que de existir cláusula compromisoria, ésta obliga a que se celebre el compromiso arbitral cuando la disputa se presente. Sin embargo, y dentro de la misma línea de Lohmann, Montoya niega que la cláusula compromisoria provoque el nacimiento del arbitraje.

Dentro de tal orden de ideas, y evaluando las definiciones dadas, puede aseverarse que la cláusula compromisoria es un acto jurídico potestativo, ya que su presencia y realización no es necesaria para que se pueda dar un compromiso o convenio arbitral. Así lo afirma Lohmann:

La doctrina se ha preguntado sobre la verdadera utilidad de la cláusula compromisoria. Se considera que no es imprescindible y que su lugar podría ser ocupado por un compromiso arbitral firme sobre toda controversia futura al que sólo le faltaría

\footnotetext{
5 Artículo derogado por la Primera Disposición Final del Decreto Ley n. ${ }^{\circ}$ 25935, publicado el 10 de diciembre de 1992.

${ }^{6}$ Lohmann Luca de Tena, Juan Guillermo. El arbitraje. «Biblioteca Para leer el Código Civil». Lima: Fondo Editorial de la Pontificia Universidad Católica del Perú, 1988, 2. ${ }^{\text {a }}$ ed., vol. v, p. 107.

${ }^{7}$ Montoya Alberti, Ulises. El arbitraje comercial. Lima: Cultural Cuzco, 1988, pp. 45 y 46.
} 
integrarse con la indicación de la materia controvertida y los árbitros, si no se hubiesen designado de antemano. La observación es razonable tanto desde un punto de vista teórico como práctico. Realmente, nada obsta que la cláusula compromisoria, acuerdo pre-arbitral o como quiera denominarse, tenga el mismo contenido que el compromiso, con la salvedad de la indicación de la materia controvertida. De ser así, ya no sería necesario otro convenio, pues suscitado el conflicto cualquiera de las partes solicitaría de la otra y de los árbitros la suscripción de un documento que, a la par de detallar las cuestiones litigiosas, constituye acta de misión de los árbitros.

Pero Lohmann (1988), al igual que Castillo, no sólo establece que la cláusula compromisoria es innecesaria y prescindible, sino que indica que es entorpecedora y anacrónica. Eso es lo que señala, a propósito de su crítica al legislador que instituyó el arbitraje de esa manera: "Nuestro legislador civil ha desestimado esta posibilidad, a mi parecer mucho más ágil, rápida y flexible, y ha optado por reproducir el sistema español, atacado de anacrónico y entorpecedor.” (p. 81)

En consecuencia, ambos autores, Castillo Freyre y Lohmann Luca de Tena, concluyen en que la cláusula compromisoria no da nacimiento a un arbitraje y, por tanto, aunque recibe el nombre de cláusula, no puede considerarse como parte de un contrato ni como un contrato en sí mismo, ni mucho menos preparatorio o principal:

En resumen, aunque el artículo 1907 le adjudique categoría contractual y de paso, implícitamente, le imponga los requisitos generales de la contratación, no queda sino concluir que lo hace de manera traslaticia para evitar tener que entrar en la tipicidad legal de pre-contrato, sobre lo cual la doctrina continúa en discordia. En lugar de haberse hablado de «contrato preliminar», que sugiere fundadas dudas, el legislador pudo haber evitado el problema y haberlo denominado acuerdo, o convenio, o cláusula compromisoria sin más. Lo preliminar a mi juicio, no significa otra cosa que acuerdo previo al surgimiento del conflicto, en previsión de él, y creándose desde tal acuerdo una singular y diferente situación jurídica para las partes: la relación jurídica, ya precisada en sus fronteras, aunque todavía no perfeccionada en su contenido.

En el estado actual de desarrollo doctrinal y legislativo, es más seguro calificar al convenio preliminar de arbitraje como un negocio jurídico con ciertas características contractuales. Es decir, no es recomendable imputar auténtico atributo precontractual típico a este convenio preliminar arbitral, no sólo por la dificultad de identificar con nitidez las señas de lo que es exactamente un pre-contrato, sino porque los alcances del preliminar exceden en mucho la exclusividad de obligarse a celebrar otro contrato. (p. 


\subsubsection{La cláusula compromisoria sí da origen al arbitraje}

Por otra parte, en el lado opuesto de la doctrina, encontramos a Pucci, quien indica que dicha cláusula sí origina el arbitraje a través de la celebración de un contrato.

Así, Pucci señala que la cláusula compromisoria: "Es un dispositivo en virtud del cual las partes, vinculadas por un contrato, establecen que las posibles controversias que surjan con motivo de dicha negociación serán resueltas por medio de arbitraje." (p. $73,74)$

Dentro del mismo rubro, Alsina (s.f) se pronuncia en similares términos a los de Pucci, al afirmar que con la cláusula compromisoria surge la obligación entre las partes de resolver sus controversias por la vía arbitral. Así: "Puede definirse la cláusula compromisoria como la obligación que contraen las partes de someter sus diferencias a la decisión de árbitros. Es anterior, por consiguiente, a toda controversia, y contempla la posibilidad de que ella se suscite [...]." (p. 29 y 30)

Dentro de tal orden de ideas, podemos establecer que la gran diferencia existente para dividir al convenio arbitral en cláusula compromisoria y compromiso arbitral, era que en esta última la controversia ya existía, mientras que en la cláusula compromisoria todavía no se había producido, es decir, el acuerdo se realizaba en base a un supuesto de hecho futuro.

Cabe hacer la salvedad de que, si bien es cierto la legislación actual, no presenta ni la figura de la cláusula compromisoria ni la del compromiso (debido a que, como se ha podido observar, dicha distinción constituía no un aporte sino una obstáculo para alcanzar la finalidad que el arbitraje se propone como medio alternativo de solución de conflictos), ello no significa de modo alguno que se prohíba a las partes para que puedan recurrir a ellas y procedan a utilizarlas como modalidades o formas para contratar. Tan es así, que en la práctica se toma a estas figuras como figuras autónomas y pueden producir el mismo efecto, es decir, el nacimiento o creación del arbitraje. ${ }^{8}$

\footnotetext{
${ }^{8}$ En este sentido, Castillo Freyre y Vásquez Kunze (Castillo Freyre, Mario y Ricardo Vásquez Kunze. El juicio privado: La verdadera reforma de la justicia. «Biblioteca de arbitraje». Lima: Estudio Mario Castillo Freyre- Palestra Editores, 2006, vol. 1, p. 69), expresan lo siguiente:

«En síntesis, podemos afirmar que dos son las modalidades para contratar un arbitraje que se pueden aprehender en mayor medida de la realidad: la cláusula arbitral, que es el pan de todos los días en el tema
} 
Lo expresado, importa un deslinde necesario pues, como ya se ha podido observar, hasta hace algunos años la discusión entre quienes defendían a la cláusula compromisoria y el sector que abogaba por el denominado compromiso arbitral, para considerar a aquélla como un contrato que da origen al arbitraje, hoy en día es un tema ampliamente superado.

Ahora bien, es preciso abordar la problemática que nos aboca y examinar el compromiso en sí mismo, ya que es a través de éste que el arbitraje se viabiliza.

\subsubsection{Teorías sobre la naturaleza jurídica del convenio arbitral}

Ahora bien, todo lo hasta aquí señalado nos servirá para tener un panorama claro y empezar a desarrollar el tema neurálgico del problema.

Así, a continuación veremos las distintas posiciones que la doctrina adopta respecto a la naturaleza jurídica del convenio arbitral (ello, al margen de las diversas denominaciones que éste tiene).

Sin embargo, cabe señalar el hecho de que algunos autores, entre ellos De la Puente (2002, p. 106) señalan que en la época moderna no se observa claramente una diferencia entre contrato, convenio y pacto, como sí sucedió en la época romana.

Dentro de tal orden de ideas, se sabe que un acuerdo puede constituir diferentes figuras jurídicas como en la convención, el contrato, el convenio, entre otros. En ese sentido, en adelante estudiaremos cada una de estas denominaciones, con el objeto de tomar posición respecto a la naturaleza jurídica de este acuerdo, denominado tentativamente «convenio arbitral».

\subsubsection{El convenio arbitral reviste la naturaleza jurídica de convenio}

Guillermo Cabanellas (1989), conceptúa al convenio como:

El concierto de voluntades, expresado en convención, pacto, contrato, tratado o ajuste (v). Sinónimo de cualquiera de estos vocablos que implican acuerdo, por la elasticidad y uso generalizado que al convenio se le da; no obstante las diferenciaciones técnicas que

de arbitraje; y el contrato de arbitraje sobre controversia producida, cuyos casos son menos comunes. La tercera modalidad, a saber, el contrato universal de arbitraje pertenece al reino de lo posible aunque básicamente no de los hechos». 
en cada remisión se concretan. (p. 365)

De esta definición se tiene que el convenio es sinónimo de una serie de palabras —esto, según Cabanellas-, teniendo como esencia característica común la existencia de un acuerdo de voluntades de dos o más personas. ${ }^{9}$ Es decir, el convenio es la raíz madre de todo acuerdo de voluntades.

Siguiendo la misma línea conceptual, la Enciclopedia Jurídica Omeba ${ }^{10}$ reconoce al convenio diversos significados, entre ellos, precisa que «constituye una acepción multívoca», en el sentido de que «diversas ramas del saber jurídico la utilizan para expresar acuerdos o coincidencias de voluntades». (La cursiva es nuestra).

Sin embargo, para entender mejor estas diferencias, que muchas veces son técnicas, pasaremos a realizar un deslinde conceptual entre convención, pacto y contrato.

Así, se tiene que para Cabanellas (1989, p. 364) existe un distingo entre convención y contrato, ya que la convención es el género y el contrato la especie.

Es decir, tanto la convención como el contrato constituyen un acuerdo de voluntades. Sin embargo, en la convención se presentará dicho acuerdo con la finalidad de constituir cualquier tipo de relaciones jurídicas, pudiendo incluirse las obligaciones; en cambio, en el contrato sólo se darán acuerdos de voluntades con la finalidad de constituir relaciones jurídicas con efectos únicamente obligacionales por ser ésta la especie de la convención.

Por lo tanto, podría decirse que todo contrato es una convención, pero no toda convención es un contrato.

El segundo término que menciona Cabanellas (1989, p. 364), como parte del concierto de acuerdo de voluntades, es el pacto; el mismo que también es definido por Cabanellas, quien indica que es el acuerdo obligatorio de voluntades; es lo así convenido.

El tercer término a que hace referencia Cabanellas (1989, p. 337, 338) es el contrato, y establece que se trata del convenio obligatorio entre dos o más partes,

\footnotetext{
${ }^{9}$ Esta afirmación se corrobora cuando el mismo autor establece como definición de convención a la palabra proveniente del latín conventio, derivada de conveniere, convenium, siendo el acuerdo de dos o más personas sobre una misma cosa o caso.

${ }^{10}$ Enciclopedia Jurídica Omeba. Buenos Aires: Editorial Bibliográfica, 1962, tomo IV, p. 803.
} 
relativo a un servicio, materia, proceder o cosa; y que éste podría caracterizarse como un acuerdo jurídico.

Sin embargo, debe indicarse que acto seguido, Cabanellas indica que aun cuando en lenguaje corriente se emplean como sinónimos de contrato otros dos términos, como son el acto jurídico y la convención; en el lenguaje del Derecho, cada una de esas palabras posee, o debería poseer, un sentido técnico preciso.

Es así que, en base a lo expuesto, el convenio arbitral estaría escribiendo una denominación correcta.

Ello, sin embargo, no obsta a que otras denominaciones también lo sean.

\subsubsection{El convenio arbitral reviste la naturaleza jurídica de un acto jurídico}

Por otra parte, es evidente que la esencia misma del acto jurídico está constituida por el acuerdo de voluntades. Dentro de tal orden de ideas, al indicar una definición acerca de «acuerdo de voluntades», De la Puente (2002) indica que esta figura era un conventio, conventum, pactio y comprendía el elemento subjetivo de los consentimientos que coinciden, o sea el acuerdo de voluntades». (p. 106)

El acto jurídico encontrará como fuente a la manifestación de voluntad, sin importar la manera de su constitución (unilateral, bilateral o plurilateral); a diferencia de la convención, que excluye a la manifestación de voluntad unilateral, ya que ella requiere de acuerdo de voluntades.

En el caso del convenio arbitral, éste formaría parte de un acto jurídico mayor, si fuese una cláusula del mismo, o también podría ser un acto jurídico autónomo, si ésa fuese la circunstancia de su celebración.

\subsubsection{El convenio arbitral reviste la naturaleza jurídica de una convención}

De la Puente indica que no existe una unificación en la doctrina respecto a este tema. Así las cosas, un sector de especialistas en la materia (que se podría considerar como el más numeroso), ${ }^{11}$ considera como convención al acuerdo de voluntades sobre un objeto

11 Como Pothier, Savigny, Aubry y Rau, Planiol, Sáchez Román, Giorgi, Mazeud, Juliot de la Morandiere, Borda, Boef, etc. Dentro del ámbito nacional, ver De la Puente y Lavalle, Manuel. «La convención y el contrato». En Advocatus. Revista editada por los alumnos de la Facultad de Derecho de 
de interés jurídico, o sea el acuerdo destinado a crear, modificar o extinguir una relación jurídica, en tanto que el contrato es el acuerdo de voluntades destinado a crear obligaciones.

Otro grupo de profesores señala, inspirándose en Domat y en los pandectistas alemanes, que el contrato cubre todo el Derecho de obligaciones y también su modificación y extinción. Ello ocasiona que pueden existir contratos consecutivos, que son los que dan lugar a la creación de una relación obligatoria; contratos modificatorios, mediante los cuales se cambian determinadas estipulaciones de otros contratos, que siguen subsistiendo; y contratos extintivos, que son aquéllos que ponen fin a obligaciones.

Finalmente, De la Puente (2002) concluye su estudio indicando que «el contrato es una especie de convención y la convención una especie de acto jurídico». (p. 109)

Tomando estas ideas, no cabe duda de que el convenio arbitral o es una convención o formará parte de ella.

\subsubsection{El convenio arbitral reviste la naturaleza jurídica de un acuerdo}

Otra posición que trata de explicar la naturaleza jurídica del convenio arbitral es la teoría adoptada por Barrios de Angelis (1956, p. 193 - 211) Este autor sostiene que la naturaleza jurídica del compromiso arbitral constituye el concepto contemporáneo de convenio arbitral, ya que ambos dan nacimiento al arbitraje.

Así, tenemos que Barrios establece que el convenio arbitral no es un contrato puro, ni un contrato procesal (aun cuando no niega sus características procesales); sino que más bien considera el convenio arbitral como un acuerdo.

Según el citado autor, la naturaleza y función jurídica del compromiso, han sido consideradas, en primer lugar, como un contrato; así, se ha podido decir que constituye un mandato, o una transacción, o un contrato sui generis. Con posterioridad, la moderna doctrina creyó ver en los defectos del compromiso una actividad procesal y lo configura como una entidad media, surge así la tesis del compromiso como un contrato procesal.

Las concepciones contractuales, que son las que dominan la doctrina, ya sea la contractual pura, o civilista, ya sea la posición media, o incluso la procesalista, son, 
para Barrios, desechables.

Para analizar el tema, Barrios indica que en el compromiso hay una causa única y común a ambas partes, ésta es, el interés en resolver el conflicto. Tratando de definir el compromiso, hay procesalistas, entre ellos Carnelutti —según Barrios-, que entienden que en el contrato existe una interdependencia de causas; la causa de uno de los contratos depende de la causa del otro. Ello, debido a que en el compromiso se da la unidad de las causas, hay un común interés de las partes en la resolución arbitral del conflicto. Por tanto, la solución contractual debe rechazarse de plano, no hay contratos sino un acuerdo.

En esta última explicación sobre la unidad, expresada por Carnelutti, se basa Barrios para negar la naturaleza contractual del «convenio arbitral». Pero, no es la única razón en la que se basa, ya que considera que es exacta pero insuficiente, porque aun cuando nos muestra de algún modo lo que es el compromiso, no nos indica para qué sirve, no nos expresa su función.

Indica que el compromiso no es algo que se agota en sí mismo, sino un acto que se realiza para algo distinto de sí, para la constitución de un juicio que debe terminar en laudo. En consecuencia, una más perfecta caracterización del compromiso debe considerarlo como un presupuesto del juicio arbitral, una condición previa y necesaria que está constituida, precisamente, por un acuerdo.

Lo expresado anteriormente, es lo que ha llevado a Barrios a concluir en que el compromiso no es un contrato, sino simplemente un acuerdo.

Asimismo, indica que el compromiso, como acuerdo, es aleatorio; su eficacia y su existencia misma dependen de la producción de actos posteriores. No sólo su eficacia, sino también su vigencia $\mathrm{y}$, con ello, su existencia, dependen de acontecimientos futuros. Como acuerdo, el compromiso tiene, por tanto, carácter aleatorio.

Teniendo en cuenta que el compromiso es un presupuesto del juicio arbitral, esto no basta por sí solo para construir el juicio, ya que es un presupuesto concurrente con otro: ese otro presupuesto es la aceptación de los árbitros. Con la aceptación, el compromiso ve cumplirse su fin inmediato, que es la constitución del arbitraje. Pero el compromiso no limita su energía o su eficacia a esta mera consecuencia de constituir el arbitraje, sino que acompaña al juicio arbitral en todas sus etapas. En consecuencia, 
Barrios agrega a las características ya señaladas, que el compromiso es un acto de adhesión y de integración jurídica.

Así, considera que es un acto de adhesión, porque mediante él las partes se acogen a un régimen o a una estructura de Derecho público establecidos por las normas procesales. En consecuencia, puede decirse que las funciones del compromiso, como presupuesto, son constitutivas, adhesivas e integrativas.

Por nuestra parte, pensamos que esta teoría, aun cuando posea cierta lógica jurídica, no se percata de que el acuerdo al que hace mención no es otra cosa que un convenio, acto jurídico, convención o contrato, como veremos más adelante.

\subsubsection{El convenio arbitral reviste la naturaleza jurídica de un contrato}

Existe un sector de la doctrina que señala que el convenio arbitral reviste todas las características de un contrato, es decir, le atribuye naturaleza jurídica contractual.

La profesora española, Aguilar Grieder (2001), señala que en el convenio arbitral existe una preponderancia del aspecto contractual sobre el procedimental, esto es, de las declaraciones de voluntad sobre los efectos procesales, en las cuestiones relativas al perfeccionamiento, validez de interpretación de la cláusula arbitral. Con base a ello, la ley aplicable será la Lex Contractus y, dentro de ella, las normas relativas a la interpretación de los contratos, las declaraciones de voluntad, etc. (p. 348)

Dentro del medio jurídico nacional, Castillo Freyre y Vásquez Kunze (2006) se suman a los autores que consideran que el convenio arbitral es un contrato: "En el tráfico jurídico y comercial de todos los días, esto es, en la realidad, los arbitrajes contratan, casi con absoluta mayoría, en lo que se conoce como cláusula arbitral. Esta cláusula es pues un contrato en toda línea.” (p. 60)

Debemos aclarar que estamos de acuerdo con Castillo y Vásquez al considerar al convenio como un contrato (por contener una relación jurídica en la que ambas partes se obligan a someterse en una posible controversia futura, al arbitraje); sin embargo, no concordamos con la denominación utilizada — la de cláusula arbitral—, ya que si el convenio arbitral no se encuentra incorporado en un contrato, no tendría sentido denominarlo cláusula, sino más bien convenio (considerando la definición que brinda Cabanellas). 
Por su parte, Guasp (1956, p. 115) establece que el arbitraje podía ir presidido de aquella promesa previa, pero ésa era un antecedente posible, no necesario, de cualquier arbitraje, aisladamente considerado. Además añade que el arbitraje propiamente dicho nace del contrato de compromiso o convenio arbitral que constituye su primer elemento indefectible.

En consecuencia, podríamos decir que Guasp, considera que el convenio arbitral debería ser considerado como un contrato, porque nace o se origina a través de la celebración de dicho contrato, esto es, a través del compromiso de resolver una controversia en la vía arbitral.

Dentro de esta misma línea de pensamiento, se pronuncia Ogayar y Ayllón (1977), quien precisa que:

Desde este punto de vista, la palabra compromiso equivale a obligación, y más especialmente a contrato. Pero también hay una acepción más restringida del «compromiso», que es la que expresa la vinculación originada por los que aceptan la decisión por terceros de una controversia. Este contrato es el que da vida a toda la institución arbitral; es su primer elemento, su antecedente obligado, el presupuesto necesario para la actuación de los árbitros. (p. 155)

Larroumett (2005) también sostiene que el acuerdo de arbitraje es un contrato en virtud del cual las partes se comprometen recíprocamente, lo que permite que dicho contrato sea de naturaleza sinalagmática. Es más, indica que al ser un contrato, éste debe cumplir con los requisitos de validez de los contratos y producir los mismos efectos. Sin embargo, el referido autor establece que dicho acuerdo posee características que tienen como objeto un acto jurisdiccional, lo cual demuestra la naturaleza dual del arbitraje. ${ }^{12}$ (p. 14)

Según Montoya Alberti (1988), el acuerdo arbitral o compromiso es un contrato definitivo, por el cual las partes se pueden ir al asunto específico obviando lo genérico, resaltando que una vez celebrado este «compromiso» existe la obligación de celebrar el compromiso arbitral cuando la disputa se presente. Así, define el compromiso como:

Un acto o convenio en virtud del cual las partes someten a la decisión de los árbitros [...] Los puntos concretos que son materia de conflicto, pudiendo, además determinar

${ }^{12}$ De modo similar se pronuncian Castillo Freyre y Vásquez Kunze (Castillo Freyre, Mario y Ricardo Vásquez Kunze. Arbitraje. El juicio privado: La verdadera reforma de la justicia. «Biblioteca de Arbitraje». Lima: Estudio Mario Castillo Freyre-Palestra Editores, vol. 1, 2006, p. 66). 
las normas de procedimiento, las condiciones de impugnaciones de laudo que dictarán los árbitros [...]. (p. 51)

En resumen, la doctrina consultada pone especial énfasis en la autonomía de la voluntad de las partes; sin embargo, existe otro sector que, aun cuando recoge la idea central de los contractualistas, incorpora características peculiares.

Así, Bernardo (2002), quien a pesar de que también considera al convenio arbitral como un contrato, establece que independientemente del carácter contractual jurisdiccional que se atribuya al arbitraje como institución, la naturaleza contractual del convenio arbitral resulta incuestionable. A continuación sus expresiones:

El convenio arbitral, a diferencia de los que podríamos denominar contratos privados «ordinarios», tiene como finalidad específica la producción de efectos procesales, no materiales. En otras palabras, la eficacia de un convenio arbitral no altera las relaciones jurídico-materiales entre las partes contratantes, pero sí incide en la forma en que éstas van a resolver las controversias que eventualmente puedan surgir. Como es bien sabido, la finalidad primordial del convenio arbitral es excluir de la jurisdicción ordinaria el conocimiento de una determinada controversia y obtener su resolución a través de un laudo que produzca los mismos efectos que una sentencia firme: cosa juzgada y ejecutoriada. (p. 7)

De la cita anterior, puede apreciarse que aun cuando la autora acepta el origen contractualista privado del convenio arbitral, indica que sus efectos se producirán en una esfera procesal, en la que predominará el interés público, ya que el Estado es, en último término, el garante de una ordenada y eficaz resolución de los conflictos intersubjetivos que evite la autotutela, y en la que subyace la renuncia «parcial»al derecho fundamental a obtener la tutela de jueces y tribunales. Así, de modo sintético, puede decirse que serían contratos procesales todos aquéllos cuyo principal efecto se produce de modo directo en el plano del proceso. ${ }^{13}$ Así, esto es lo que los diferencia de los contratos privados de derecho sustantivo, cuyo efecto principal tiene lugar en la esfera del derecho material; es decir, en los contratos privados se produce un efecto en el interior de la relación de las partes, ya que surgen deberes y derechos.

\footnotetext{
${ }^{13}$ Según Bernardo San José, siguiendo a Chiovenda, «el contrato procesal tiene por contenido la reglamentación convencional del proceso — ejemplo típico, el pacto de foro prorrogando- o la renuncia de derechos que se hacen valer mediante el proceso — ejemplo, pacto de no pedir, compromiso arbitral—. Es característica constante de los contratos procesales la de desarrollar posteriormente su eficacia en el proceso futuro o pendiente, de manera que la parte pueda obtener su actuación contra la otra parte oponerse cuando se intentare hacer, contraviniendo el contrato». (Pincipios de Derecho Procesal Civil, I, traducido por José Casáis y Santaló, Madrid, 1925, pp. 125 y ss.).
} 
Concluyendo con la opinión de Alicia Bernardo para sustentar esta tesis, tenemos que ella encuentra la eficacia procesal que atribuye al convenio arbitral, pues supone el ejercicio, por las partes, de su derecho a sustraer el litigio del conocimiento de la jurisdicción para atribuírselo a los árbitros. Es en esta exclusión de la jurisdicción pública y atribución a árbitros, la razón básica en la que descansa la autora.

Por su parte, y retomando la posición de Larroumet al hablar sobre la exclusión de la jurisdicción pública, éste expresa que: «[...] si el acuerdo de arbitraje se aproxima a una cláusula relativa a la competencia del juez estatal en la medida en que, como esta última, el acuerdo de arbitraje prepara un acto jurisdiccional, el aspecto jurisdiccional es distinto y mucho más completo, puesto que las partes en el acuerdo excluyen la competencia de los jueces estatales a favor de la de los árbitros».

En consecuencia, tomando en cuenta las posiciones de los autores citados, queda claro que la característica de provocar una sustracción de la jurisdicción pública es propia del arbitraje, es decir, del contrato que produzca el verdadero nacimiento u origen del arbitraje. Por ello, Christian Larroumet, explicando la posición que adopta la legislación francesa, señala que el objetivo del acuerdo de arbitraje es excluir la competencia de los jueces estatales, cualesquiera que sean estos jueces.

Queda claro, pues, a juicio nuestro, que el convenio arbitral puede ser considerado un contrato o, en todo caso, una cláusula contractual, como ocurre en la mayoría de veces. En él se presentan todas las características de los contratos que dan nacimiento a obligaciones de hacer y de no hacer (como, por ejemplo, no recurrir a la jurisdicción ordinaria).

\subsubsection{El convenio arbitral entendido como contrato diferente e independiente del contrato principal}

Un punto aparte — que es conveniente aclarar — es el que concierne a la autonomía del convenio arbitral, sea cual fuere la posición que se tome respecto a la naturaleza jurídica de dicha figura.

Se sabe que el convenio arbitral puede pactarse por separado, es decir, en un contrato independiente, o también puede pactarse en el que las partes se comprometen a distintas prestaciones; pero lo normal es que figure como cláusula dentro de un contrato principal. Por eso, en la práctica, suele hablarse de cláusula arbitral. 
En cualquier caso el convenio arbitral es un contrato diferente e independiente del contrato principal.

El convenio arbitral tiene fundamento y finalidad diversos de los que puede tener el contrato principal; razón por la cual, en caso surja alguna controversia sobre la validez del contrato principal, la cláusula arbitral contenida en dicho contrato no sufrirá los efectos de dicha situación.

La accesoriedad, en síntesis, alude a la dependencia documental o respecto de una relación jurídica, de la cual el cual el convenio trae su razón y su utilidad. Obviamente, este carácter autónomo del convenio pre-arbitral, también lo independiza — salvo pacto expreso- del resto del contenido de las demás estipulaciones que pudiera haberse incluido en el negocio que crea la relación jurídica, tales como condición, plazo, etc.

Así lo establece Bernardo, al indicar que: "La autonomía del convenio arbitral significa, en primer lugar, lo que el precepto dice, esto es, que la eventual nulidad del contrato principal en el que el pacto arbitral se encuentra inserto no se extiende al pacto mismo. “

Dicha afirmación es ratificada por Castillo Freyre y Vásquez Kunze (2006), al precisar que:

El contrato arbitral, conforme a la doctrina y la legislación expuesta no es más que contrato de arbitraje en toda regla al que, para variar, se le escamotea el nombre de contrato de arbitraje. Cuando éste «adopta la forma de una cláusula incluida en un contrato» no estamos más que en presencia de una cláusula arbitral a través de la cual se contrata un arbitraje. Cuando el susodicho convenio se expresa mediante un «acuerdo independiente», bien podemos estar ante un contrato de arbitraje sobre controversia producida en el caso de un conflicto de intereses ex ante el contrato de arbitraje, o bien ante un hipotético contrato universal de arbitraje. (p. 71)

Por ello, se dice que ambos emanan de sendas declaraciones de voluntad diferentes o, por lo menos, dirigidas a fines diversos: el contrato principal, a regular las relaciones jurídico-materiales entre las partes contratantes, y el convenio arbitral, a desplazar la jurisdicción, encomendando a los árbitros la resolución de los conflictos que puedan surgir.

Por otra parte, Bernardo (2002, p. 18) indica que la autonomía del convenio 
arbitral conlleva al menos tres consecuencias más:

En primer lugar, expresa que significa que puede aplicarse al convenio arbitral una normativa diferente de la que regula el contrato base, de especial utilidad en el arbitraje internacional. En segundo lugar, supone también que la eficacia del convenio, tanto positiva (vinculando a las partes al arbitraje) como negativa (excluye de la jurisdicción ordinaria), se extiende al enjuiciamiento de la validez o nulidad del contrato principal. Como dice Albadalejo, la doctrina de la autonomía del convenio arbitral ha surgido «porque se intenta salvar el tal pacto arbitral para que, en virtud de él, se pueda juzgar de la validez o no del contrato arbitrable».

Por último, a nuestro entender, la autonomía supone, además, que la eficacia del convenio arbitral alcance incluso el enjuiciamiento sobre la validez o nulidad del propio convenio arbitral. De este modo, si el actor solicita la nulidad del convenio con el propósito de excluir determinadas controversias del arbitraje, el demandado podrá proponer con éxito la declinatoria.

Nosotros concordamos con las ideas planteadas acerca de la autonomía del convenio arbitral, ya que aun en el caso de que forme parte de un contrato, este convenio sigue poseyendo su propia naturaleza y fin para el cual ha sido constituido por las partes; por ello, se dice repetidamente que en caso este convenio formara parte de un contrato en el que está en riesgo su validez, el convenio no se ve afectado. Entonces, el convenio arbitral es un contrato diferente e independiente del contrato principal.

\subsubsection{La posición del legislador nacional}

En definitiva, y teniendo en cuenta todo lo señalado, debe resaltarse que la discusión realizada en la doctrina trajo como consecuencia que los legisladores descartaran la permanencia, en la ley, de la cláusula compromisoria y el compromiso arbitral. Es así que la Ley General de Arbitraje (Decreto Ley n. ${ }^{\circ} 25935$ ) que rigió del 9 de diciembre de 1992 al 4 de enero de 1996, apeló a la figura conocida en la doctrina y en la legislación extranjeras como convenio arbitral.

Sin embargo, es con la Ley n. ${ }^{\circ}$ 26572, Ley General de Arbitraje (vigente desde el 5 de enero de 1996 hasta el 31 de agosto de 2008), que se estableció que el denominado convenio arbitral posea todos los caracteres que la doctrina contemporánea le atribuye. Dicha ley no repitió el grave error de la anterior, y define correctamente el 
convenio arbitral en su artículo 9, al señalar lo siguiente:

Artículo 9.- Definición del convenio arbitral.- El convenio arbitral es el acuerdo por el que las partes deciden someter a arbitraje las controversias que hayan surgido o puedan surgir entre ellas respecto de una determinada relación jurídica contractual o no contractual, sean o no materia de un proceso judicial. El convenio arbitral obliga a las partes y a sus sucesores a la realización de cuantos actos sean necesarios para que el arbitraje se desarrolle, pueda tener plenitud de efectos y sea cumplido el laudo arbitral. El convenio arbitral puede estipular sanciones para la parte que incumpla cualquier acto indispensable para la eficacia del mismo, establecer garantías para asegurar el cumplimiento del laudo arbitral, así como otorgar facultades especiales a los árbitros para la ejecución del laudo en rebeldía de la parte obligada. Independientemente de lo dispuesto en el párrafo anterior, los árbitros se encuentran facultados para interponer multas hasta por un máximo de dos (2) Unidades Impositivas Tributarias a la parte que no cumpla sus mandatos. Estas multas que serán en favor de la otra parte, constarán en el laudo arbitral y se ejecutarán conjuntamente con este último.

De esta manera, independientemente del momento en que se suscriba el acuerdo de arbitraje (antes o después de que surja la controversia), sólo existiría un contrato: «el convenio arbitral».

La Ley General de Arbitraje, Ley n. ${ }^{\circ}$ 26572, dejó de regir el 30 de agosto de 2008, en virtud de lo establecido por el Decreto Legislativo n. ${ }^{\circ} 1071$, el mismo que también recoge el concepto de convenio arbitral. Es así, que la ley que rige a partir del 1 de septiembre de ese año, define en su artículo 13, inciso 1 al convenio arbitral de la siguiente manera:

\section{Artículo 13.- Contenido y forma del convenio arbitral}

1. El acuerdo arbitral es un acuerdo por el que las partes deciden someter a arbitraje todas las controversias con ciertas controversias que habían surgido o puedan surgir entre ellas respecto de una determinada relación jurídica contractual o de otra naturaleza [...].

Cabe resaltar que, de la definición del convenio arbitral que contiene el artículo 9 de la Ley General de Arbitraje, Ley n. ${ }^{\circ}$ 26572, se desprendían dos defectos fundamentales, que bien se podrían aplicar a la actual regulación que hace del convenio el Decreto Legislativo n. ${ }^{\circ} 1071$.

Así las cosas, por un lado, el llamado efecto positivo, el cual consiste en la 
obligación de las partes de someter a arbitraje las controversias que hayan surgido o puedan surgir de una determinada relación jurídica, así como la obligación de cumplir la decisión de los árbitros. Por otro lado, el denominado efecto negativo, que se traduce en la prohibición a los órganos de la jurisdicción estatal de conocer tales cuestiones.

\subsubsection{La posición de la legislación extranjera}

Teniendo en cuenta lo señalado hasta aquí, creemos importante hacer referencia a cómo es que se regula el tema bajo análisis a nivel de la legislación extranjera, pues, como se sabe, nuestra tradición jurídica tiene influencia de otros sistemas jurídicos, los cuales aportan directa o indirectamente para que las leyes que rigen en nuestro territorio tengan cada vez menos diferencias.

Así, a la Ley Modelo Uncitral (que por sus siglas significa United Nations Commission on International Trade Law), al definir al convenio arbitral utiliza la denominación de «acuerdo», y establece en su artículo 7, inciso 1, lo siguiente:

\section{Articulo 7.- $[\ldots]$}

1) El «acuerdo de arbitraje» es un acuerdo por el que las partes deciden someter a arbitraje todas las controversias o ciertas controversias que hayan surgido o puedan surgir entre ellas respecto de una determinada relación jurídica, contractual o no contractual. El acuerdo de arbitraje podrá adoptar la forma de una cláusula compromisoria incluida en un contrato o la forma de un acuerdo independiente [...].

Por su parte, la Convención de Panamá, en su artículo 1, define el convenio arbitral como:

Artículo 1.- [...] el acuerdo de las partes en virtud del cual se obligan a someter a decisión arbitral las diferencias que pudiesen surgir o que hayan surgido entre ellas con relación a un negocio de carácter mercantil. El acuerdo respectivo constará en el escrito firmado por las partes o en el canje de cartas, telegramas o comunicaciones por télex.

Por su parte, en Ecuador, la Ley n. ${ }^{\circ}$ 000.RO/145, del 4 de septiembre de 1997, señala que:

Artículo 5.- El convenio arbitral es el acuerdo escrito en virtud del cual las partes deciden someter a arbitraje todas las controversias o ciertas 
controversias que hayan surgido o puedan surgir entre ellas respecto de una determinada relación jurídica, contractual o no contractual. [...]

De otro lado, en Chile, la Ley n. ${ }^{\circ} 19.971$ prescribe que:

Artículo 7.- Definición y forma del acuerdo de arbitraje.

1) El «acuerdo de arbitraje» es un acuerdo por el que las partes deciden someter a arbitraje todas las controversias o ciertas controversias que hayan surgido o puedan surgir entre ellas respecto de una determinada relación jurídica, contractual o no contractual. El acuerdo de arbitraje podrá adoptar la forma de una cláusula compromisoria incluida en un contrato o la forma de un acuerdo independiente. [...]

Entre tanto, en España, la Ley n. ${ }^{\circ}$ 60/2003, establece en su Título II «Del convenio arbitral y sus efectos», artículo 9, lo siguiente:

\section{Artículo 9.- Forma y contenido del convenio arbitral.}

1. El convenio arbitral, que podrá adoptar la forma de cláusula incorporada a un contrato o de acuerdo independiente, deberá expresar la voluntad de las partes de someter a arbitraje todas o algunas de las controversias que hayan surgido o puedan surgir respecto de una determinada relación jurídica, contractual o no contractual. [...]

Asimismo, Bolivia, a través de la Ley n. ${ }^{\circ}$ 1770, ley de 10 de marzo de 1997, indica que:

Artículo 10.- I. El convenio arbitral se instrumenta por escrito, sea como cláusula de un contrato principal o por acuerdo separado del mismo. Su existencia deriva de la suscripción de un contrato principal o de un convenio arbitral específico o del intercambio de cartas, télex, facsímiles o de cualquier otro medio de comunicación, que deje constancia documental de la voluntad de ambas partes de someterse al arbitraje.

Dentro de esta misma línea legislativa, tenemos a Paraguay, país que a través de la Ley n. ${ }^{\circ} 1.879 / 02$, establece en su artículo 3, que:

Artículo 3.- Definiciones. A los efectos de la presente ley, se entenderá por:

a) Acuerdo de arbitraje: el pacto por el cual las partes deciden someter a arbitraje todas o ciertas controversias que hayan surgido o puedan surgir entre ellas respecto de una determinada relación 
jurídica, sea o no contractual. El acuerdo de arbitraje podrá adoptar la forma de una cláusula compromisoria incluida en un contrato o la forma de acuerdo independiente. [...] 


\section{CAPÍTULO II: CLASIFICACIÓN DEL CONVENIO ARBITRAL}

\subsection{Concepto}

Conforme a lo establecido por el inciso 1 de la Ley de Arbitraje, el convenio arbitral es un acuerdo por el que las partes deciden someter a arbitraje, todas las controversias o ciertas controversias que hayan surgido o puedan surgir entre ellas respecto de una determinada relación jurídica contractual o de otra naturaleza.

Puede deducirse claramente del contenido de la norma citada, que el convenio arbitral implica un acuerdo de voluntades, y el objeto central de este acuerdo de voluntades, es contemplar la posibilidad de que la solución de determinadas controversias que surjan en el futuro, sea sometida a arbitraje.

\subsubsection{El necesario origen contractual}

La libertad de contratar implica un doble concepto. Por un lado, la libertad de contratar propiamente dicha, y por otro, la libertad contractual o de configuración interna.

Más allá de la doble naturaleza de este concepto, es decir, la libertad de contratar y la libertad contractual o de configuración interna, resulta evidente que a nadie se le puede imponer en el Perú, la celebración obligatoria de un contrato (salvo en casos de excepción).

Esta plena libertad rige, por tanto, en materia arbitral, en donde el apartamiento de la jurisdicción ordinaria, debe ser absolutamente voluntario y no forzoso.

En conclusión, el convenio arbitral es esencialmente y por naturaleza, voluntario. 


\subsection{Clasificación del convenio arbitral}

Consideramos que existen diversos criterios en virtud de los cuales se podría clasificar el convenio arbitral.

\subsubsection{Según el momento en que se pacta}

\section{a) Antes del surgimiento del conflicto}

Usualmente, los convenios arbitrales prevén la existencia de un conflicto, a efectos de que cuando éste se produzca (si tal evento llegara a ocurrir), las partes solucionarán sus controversias en la jurisdicción arbitral.

Por lo demás, ése resulta el momento idóneo para pactar el convenio arbitral, en la medida de que cuando se celebra un contrato y se da nacimiento a determinadas obligaciones, la expectativa de las partes para el cumplimiento futuro de tales obligaciones es óptimo y, naturalmente, la relación entre ambas es cordial; elementos que estimamos indispensables para que las partes puedan acordar un convenio arbitral, en la sana previsión de que un eventual e indeseable conflicto se resolverá de la manera más rápida posible $\mathrm{y}$, precisamente, dicho convenio se pactará cuando no tengamos frente a nosotros a una parte incumpliente, y que en virtud de su propio incumplimiento, podrá estar interesada en retardar la solución de esa controversia en la que tendrá todas las de perder.

\section{b) Con posterioridad al surgimiento del conflicto}

Aunque resulta bastante inusual, es perfectamente factible que las partes convengan en la celebración de un convenio arbitral, con posterioridad al surgimiento de una controversia entre ambas.

Tal situación podría derivarse de distintos escenarios. Uno primero, sería aquél en el cual, en el contrato que vinculaba a las partes, éstas no habían celebrado convenio arbitral alguno y ellas, con el ánimo de que la controversia se solucione de una manera rápida $\mathrm{y}$, en cierta forma, amigable o poco hostil, deriven dicha solución a la jurisdicción arbitral, en razón de haber acordado un convenio arbitral, precisamente, 
con posterioridad al surgimiento de tal controversia.

Situaciones como ésta se observan, fundamentalmente, cuando nos encontramos en presencia de dos partes que tienen entre sí antiguas, estrechas o notorias relaciones comerciales, que aspiran a continuar, luego de solucionada la controversia y que trascienden con holgura los alcances y términos de la misma.

Una segunda situación en la que podría celebrarse un convenio arbitral, con posterioridad al surgimiento de la controversia, sería el caso en el cual las partes hubiesen incluido un convenio arbitral en el contrato que las vinculaba, pero caigan en la cuenta de que los alcances del convenio resultan insuficientes para recurrir la jurisdicción arbitral en la solución del conflicto surgido.

En razón de ello, y de complementar los alcances del convenio arbitral celebrado con anterioridad, las partes podrían recurrir a celebrar un nuevo convenio arbitral que sustituya o que complemente los términos del anterior.

Si bien hasta este punto nos hemos referido a casos en los cuales la controversia se derive de una relación contractual, bien podríamos imaginar un tercer escenario en el cual la controversia surja de un supuesto de responsabilidad civil extracontractual (artículos 1969 y siguientes del Código Civil de 1984).

Dentro de tal orden de ideas, producido el acto dañoso y ante la ausencia de un convenio arbitral, las partes podrían perfectamente celebrar dicho convenio a efectos de solucionar tales controversias en esta jurisdicción y no en la ordinaria.

Ello, naturalmente, se producirá sólo en los casos en que la parte causante del daño tenga la voluntad y la disposición de solucionar el problema de manera justa y célere.

\subsubsection{Según si constituye una cláusula contractual o un contrato independiente}

\section{a) El convenio arbitral como cláusula contractual}

Puede derivarse fácilmente del primer criterio clasificatorio que el convenio arbitral de manera usual constituye parte de un contrato mayor, es decir, por lo general, está redactado a modo de cláusula contractual, en donde se establecen los alcances y 
características que tendrá la solución de controversias en esta vía.

\section{b) El convenio arbitral como contrato independiente}

En la medida de que el convenio arbitral se ha celebrado de manera independiente, ya sea para establecer la jurisdicción arbitral ante su existencia, o para complementar los alcances de un convenio anterior incluido en un contrato ${ }^{14} \mathrm{o}$, finalmente, cuando el convenio arbitral se pacta para solucionar controversias derivadas de la responsabilidad extracontractual, es claro que en estos casos el convenio arbitral será en sí mismo un contrato, y no sólo cláusula de un contrato mayor.

No obstante, debemos señalar que los efectos prácticos de una situación o de otra, serán exactamente los mismos dentro de la legislación nacional.

\subsubsection{Según el número de partes}

El convenio arbitral puede ser bilateral, plurilateral o unilateral.

\section{a) Bilateral}

Siendo usual que los convenios arbitrales provengan de relaciones contractuales, es también usual que éstas se hallen conformadas por sólo dos partes.

No existiendo una estadística sobre este particular, es evidente que la doctrina contractual coincide en asumir que el grueso de contratos es celebrado estrictamente por dos partes, de ahí que la inmensa mayoría de convenios arbitrales tengan también origen bilateral.

\section{b) Plurilateral}

Teniendo en cuenta que el contrato es, sin lugar a dudas, el instrumento de relación patrimonial de los seres humanos por excelencia, y considerando las muy variadas formas contractuales que existen en el mundo contemporáneo, cada día resulta más usual apreciar la existencia de contratos plurilaterales, es decir, de aquéllos celebrados

\footnotetext{
${ }^{14} \mathrm{Si}$ bien se celebra en documento independiente, queda en evidencia que las modificaciones quedan integradas al convenio arbitral, que forma parte del contrato que se inserta.
} 
por más de dos partes.

En estos casos también se puede pactar la existencia de convenios arbitrales.

Sin embargo, siempre deberá tenerse presente que los contratos plurilaterales presentarán como inconveniente conceptual al momento de iniciarse el arbitraje, el relativo al nombramiento de los árbitros, en la medida de que, salvo disposición diversa del propio convenio arbitral, no es que cada parte contractual vaya a nombrar un árbitro, sino que los árbitros de parte deberán ser nombrados, uno, por las partes contractuales que sean la parte demandante, y el otro, por las partes contractuales que sean la parte demandada; siendo evidente que ambos árbitros elegirán al presidente del tribunal.

Aunque no se trata de un tema que desarrollaremos en este trabajo, debemos dejar constancia de que éste es uno de los que genera la más encendidas controversias en los procesos arbitrales.

Pero, en este rubro también se halla el convenio arbitral inserto en un estatuto social. Pluralidad de partes, un solo contrato y un solo convenio arbitral a invocar para solucionar sus controversias.

\section{c) Unilateral}

Aunque parezca extraño, por excepción los «convenios arbitrales» pueden ser celebrados por una sola parte, como es el caso de los convenios arbitrales contenidos en los testamentos, supuesto contemplado por la Séptima Disposición Complementaria de la Ley de Arbitraje, que en estricto es una cláusula testamentaria arbitral, obviamente contenida en un acto que en el Perú es, por esencia, unilateral.

En estos casos, lo establecido por el testador, obligará a quienes sean sus sucesores (herederos y legatarios), además de los albaceas, a resolver en arbitraje las controversias que se pudieran suscitar entre ellos, incluidas las relativas al inventario de la masa hereditaria, su valoración, administración y partición.

Es evidente, por cierto, que como lo establece el segundo párrafo de la mencionada Séptima Disposición Complementaria de la Ley de Arbitraje, si no hubiese testamento o el testamento no contemplara una estipulación arbitral, los sucesores y los albaceas, perfectamente podrían celebrar — con posterioridad - un convenio arbitral para resolver las controversias antes mencionadas. 


\subsubsection{Según a quiénes comprende sus efectos}

\section{a) Efectos restringidos a las partes que lo celebran}

Constituye regla general dentro del Derecho peruano, conforme lo establece el artículo 1363 del Código Civil, que los contratos sólo producen efectos entre las partes que los celebran y sus herederos, salvo en cuanto a éstos, si se trata de derechos y obligaciones no transmisibles.

Es evidente, además, que cuando nos encontramos ante la situación usual de un convenio arbitral que haya sido incluido como cláusula de un contrato o como contrato independiente, los efectos de dicho convenio, sólo se circunscribirán a las partes que lo han celebrado, dentro de los alcances del artículo 1363 del Código Civil.

\section{b) Efectos que comprenden a terceros}

Sin embargo, hay casos en los cuales los alcances del convenio arbitral se extienden a partes que no lo celebraron.

La legislación arbitral peruana regula expresamente dos casos.

El primero, es el arbitraje testamentario, sobre cuyas características ya hemos tratado.

El segundo, es el arbitraje estatutario, regulado en la Sexta Disposición Complementaria de la Ley de Arbitraje.

Dicha norma establece que puede adoptarse un convenio arbitral en el estatuto de una persona jurídica ${ }^{15}$ para resolver las controversias entre la persona jurídica y sus miembros, directivos, administradores, representantes y funcionarios, o las que surjan entre ellos, respecto a sus derechos u obligaciones, o las relativas al cumplimiento de los estatutos, o la validez de los acuerdos.

\footnotetext{
${ }^{15}$ Tómese nota de que dicha Disposición Complementaria, hace referencia al convenio arbitral en el estatuto de una persona jurídica en general; es decir, que la posibilidad de adoptar el arbitraje estatutario se extiende a todo tipo de persona jurídica que contenga un estatuto, tales como sociedades anónimas, sociedades comerciales de responsabilidad limitada, sociedades civiles, empresas individuales de responsabilidad limitada, asociaciones, fundaciones y comités.
} 
La referida norma agrega que el convenio arbitral alcanza a todos los miembros, directivos, administradores, representantes y funcionarios que se incorporen a la sociedad, así como a aquéllos que al momento de suscitarse la controversia, hubiesen dejado de serlo.

Es evidente, entonces, que el referido convenio arbitral estatutario, no sólo se extiende a quienes lo celebran, es decir, a los socios, titulares, asociados o fundadores de la persona jurídica, sino a una serie de personas más, como es el caso de directores, administradores, representantes y funcionarios que, formando parte de la persona jurídica, evidentemente, no han celebrado dicho convenio arbitral.

Pero no sólo eso, pues el convenio arbitral estatutario también se extenderá a los directores, representantes y funcionarios de la persona jurídica que ingresen a ella en el futuro, y a aquéllos que ingresen a trabajar como administradores para la persona jurídica en el futuro, incluyendo a quienes adquieran la calidad de socios o asociados con posterioridad a la celebración del referido convenio arbitral. ${ }^{16}$

Esta característica es importante, pues ella constituye una situación excepcional a la regla del artículo 1363 del Código Civil, la misma que resulta válida en función a dos razones.

La primera, pues se trata de una modificación a la regla establecida por norma legal de similar jerarquía, en tanto el Código Civil y la Ley de Arbitraje, fueron promulgados vía decreto legislativo, lo que equivale a que ambos cuerpos normativos tienen rango de ley.

Además, la Ley de Arbitraje sólo establece esta excepción a los alcances del convenio arbitral con respecto de terceros no suscriptores del mismo, habida cuenta de que dicha excepción no regirá para los demás actos o estipulaciones contractuales, a cuyo efecto continúa siendo regla, la contenida en el artículo 1363 del Código Civil.

Es necesario señalar también que en el caso del arbitraje estatutario, el convenio

\footnotetext{
${ }^{16} \mathrm{Al}$ respecto cabe señalar, que lo dispuesto en la Sexta Disposición Complementaria de la Ley de Arbitraje, debe ser interpretado tomando en consideración la legislación laboral. En efecto, la nueva Ley Procesal del Trabajo (Ley n. ${ }^{\circ}$ 29497), establece en la Sexta Disposición Complementaria, que «Las controversias jurídicas en materia laboral pueden ser sometidas a arbitraje, siempre y cuando el convenio arbitral se inserte a la conclusión de la relación laboral y, adicionalmente, la remuneración mensual percibida sea, o haya sido, superior a las setenta (70) Unidades de Referencia Procesal».

En este sentido, se entenderá que el arbitraje estatutario, no sería aplicable para aquellos miembros, directivos, administradores, representantes y funcionarios, que además de desempeñarse como tales, tengan la calidad de trabajadores de la persona jurídica y, siempre y cuando, la controversia jurídica se relacione o derive de derechos laborales.
} 
arbitral no alcanza a las convocatorias a juntas, asambleas o consejos o cuando se requiera una autorización que exija la intervención del Ministerio Público.

En los casos de arbitraje estatutario, resulta fundamental para que sus efectos se extiendan a terceros no suscriptores, el hecho de que el estatuto social se encuentre inscrito en los Registros Públicos; ello, en la medida de que sólo la publicidad hará que dicho convenio arbitral estatutario tenga efectos con respecto a los terceros no suscriptores que todavía no ostenten la calidad de socios, asociados, accionistas, directivos, administradores o representantes; o para quienes se incorporen en cualquiera de dichas calidades en el futuro.

Por lo demás, los efectos del convenio arbitral con respecto a terceros no suscriptores, podrían ser perfectamente cuestionados por aquellos miembros ${ }^{17}$ que se hubieren opuesto expresamente a la modificación de un estatuto que antes no incluía al arbitraje estatutario.

Decimos esto, en la medida de que en este caso, será claro que no podría aplicarse la ficción de haber manifestado voluntad alguna en favor del convenio, habida cuenta de que habría negativa o rechazo expreso respecto al mismo.

Para tales efectos, el miembro o su representante, de ser el caso, deberá dejar constancia en el acta del sentido de su voto. Ello, en concordancia con el artículo 135 de la Ley General de Sociedades, Ley n. ${ }^{\circ} 26887$, que señala:

Artículo 135.- Contenido aprobación y validez de las actas

En el acta de cada junta debe constar el lugar, fecha y hora en que se realizó;

la indicación de [...]; el nombre de los accionistas presentes o de quienes representen; [...]; la forma y resultado de las votaciones y los acuerdos adoptados.

$[\ldots]$

Cualquier accionista concurrente o su representante y las personas con derecho a asistir a la junta general están facultados para solicitar que quede constancia en el acta del sentido de sus intervenciones y de los votos que hayan emitido.

[...]

${ }^{17}$ Entendemos por miembros, a los socios, titulares, asociados, fundadores y/o miembros de comités. 
El acta tiene fuerza legal desde su aprobación.

Dentro de tal orden de ideas, el acuerdo que incorpora un convenio arbitral estatutario como medio de resolución de controversias, no obliga al accionista que se opuso a la modificación de un estatuto que antes no incluía al arbitraje estatutario y dejó constancia expresa de su rechazo en el acta.

El mismo argumento sería aplicable por extensión para los socios, asociados, fundadores y miembros de comités; toda vez que donde hay la misma razón, hay el mismo derecho.

\subsubsection{Según sus alcances}

\section{a) Cualquier controversia}

Es el caso de los convenios arbitrales que establecen que cualquier controversia que se suscite entre las partes relativa la celebración o ejecución del contrato, será sometida a la jurisdicción arbitral.

Si fuera voluntad de las partes el someter cualquier controversia que se suscite en ellas a arbitraje, entonces, deberán expresarlo claramente en el convenio arbitral.

Decimos esto, en la medida de que son muchos los casos en los que se aprecia la existencia de cláusulas patológicas en las que, si bien fue la intención de las partes el someter cualquier futura controversia a arbitraje, la redacción del convenio arbitral contradice esa supuesta intención.

Si se desea que el convenio arbitral comprenda cualquier futura controversia, las partes, fundamentalmente, tendrán que tener en consideración dos rubros, los mismos que podrían ser contemplados o precisados, pero sin cuya inclusión o precisión, el convenio arbitral que desean celebrar se encontraría incompleto y, por tanto, sería patológico.

Así las cosas, es fundamental que las partes incluyan en el texto del convenio arbitral, las controversias derivadas de la celebración del acto, y aquéllas que se derivan de su ejecución.

Pasemos a analizar ambos casos. 
El contemplar las controversias derivadas de la celebración de un contrato, resulta en extremo importante, en la medida de que es el momento de la celebración donde pueden presentarse algunos vicios que ulteriormente generen controversias entre tales partes y que, técnicamente hablando, sólo estarán presentes al momento de la celebración del contrato y no en ocasión posterior.

Como sabemos, es en la celebración donde se presentan los eventuales problemas relativos a la nulidad de los contratos, cuyas causales se encuentran reguladas de manera minuciosa por el artículo 219 del Código Civil.

Eso significa que si no se contempla este extremo del convenio arbitral, no podrá ser discutida en arbitraje ninguna controversia referida a nulidades.

Lo propio ocurre con los casos de anulabilidad de los actos jurídicos y contratos, materia regulada en detalle en el artículo 221 del Código Civil.

Como es evidente, todas las causales de anulabilidad de los contratos, al igual que todas las causales de nulidad de los mismos, consisten en vicios cuya presencia se ubica al momento de la celebración de tales contratos, de modo que, de no haberse contemplado en un convenio arbitral las controversias relativas a la celebración del acto, tales controversias deberán ser resueltas en la jurisdicción ordinaria y no en la arbitral.

Por lo demás, debemos decir lo propio con respecto a cualquier alegación de invalidez del contrato, pues dentro de la regulación legal peruana, la invalidez es un efecto natural de la nulidad y de la anulabilidad, razón por la cual, si un convenio arbitral no contemplara las controversias relativas a la celebración del contrato, cualquier alegación de invalidez, también deberá ser resuelta en la jurisdicción ordinaria y no en la arbitral.

Y no sólo eso, pues en el Derecho contractual peruano existe un tercer caso de vicios de origen, presente al momento de la celebración del contrato. Es el de la rescisión, materia regulada de modo general por los artículos 1370 y 1372 del Código Civil, y de manera específica, por los supuestos legales de lesión (artículo 1447), compraventa sobre medida (artículo 1575), venta de bien total o parcialmente ajeno (artículos 1539 y 1540 , respectivamente), entre otros.

Los casos de rescisión plantean la existencia de vicios de origen, los mismos que no podrían ser de conocimiento de la jurisdicción arbitral, en caso no se hubiere pactado 
en el convenio, las controversias relativas a la celebración del contrato.

Es necesario advertir además que cualquier alegación de ineficacia derivada de la rescisión contractual o de la nulidad o invalidez del contrato, se regirá estrictamente por todo lo que acabamos de expresar.

Por otra parte, para que los convenios arbitrales comprendan la solución de cualquier controversia que se genere entre las partes, deberán también referirse a los conflictos o controversias relativos a la ejecución de los contratos.

La expresión «ejecución de los contratos» es lo suficientemente amplia como para comprenderse en ella a todas las controversias relativas a la ejecución propiamente dicha, vale decir, al cumplimiento, como, evidentemente, a los defectos de cumplimiento, lo que equivale a decir que estarían comprendidas en el convenio arbitral, todas las controversias o reclamos que se deriven de un cumplimiento parcial, excesivo, tardío, anticipado o defectuoso, además de, claro está, aquéllas relativas al incumplimiento total de la obligación.

Es claro para nosotros que todas estas variantes del incumplimiento contractual pueden constituir alegaciones y controversias referidas a la ejecución o cumplimiento del propio contrato.

Sobre este rubro, hay que expresar que las partes tendrán la más absoluta libertad, si así lo consideran conveniente a sus intereses, de efectuar las precisiones que desean en torno a las controversias relativas a la celebración y ejecución del contrato, en aras de lograr el mayor detalle o precisión.

Sin embargo, es aconsejable que dicho detalle sea, en todo caso, lo suficientemente exhaustivo como para que el mismo no desnaturalice la amplitud de la expresión de que cualquier controversia relativa a la celebración o ejecución del contrato, será arbitrable.

\section{b) Algunas controversias}

Se deduce fácilmente de lo expuesto en el punto anterior que, ya sea por voluntad propia de las partes, o por inadvertencia (convenio patológico), el convenio arbitral podría no comprender todas las controversias susceptibles de suscitarse entre las partes, sino sólo algunas. 
Más allá de los casos en que esto ocurra por inadvertencia o mala redacción del convenio arbitral, si tal decisión fuese voluntaria, generalmente, encontrará explicación en la voluntad de las partes de reservar algunas de sus eventuales controversias a la jurisdicción ordinaria, en donde — tal vez- hallen mayor seguridad debido a la pluralidad de instancias.

\subsubsection{Según exista o no negociación previa del convenio arbitral}

\section{a) Convenios arbitrales por negociación previa}

Como sabemos, los contratos se dividen en aquéllos paritarios o de negociación previa, es decir, aquellos contratos cuyo contenido ha sido libremente formado y discutido por las partes en su integridad, sin la existencia de formatos preestablecidos e impuestos por una de las partes.

No cabe duda de que esta clasificación general de los contratos puede extenderse a los convenios arbitrales, en donde, en infinidad de casos, los textos de los convenios arbitrales son negociados por las partes que los celebran, sin restricción alguna.

Podríamos hablar, incluso, de que en estos casos existe en las partes plena libertad contractual o de configuración interna con respecto a la definición del contenido del convenio arbitral.

\section{b) Convenios arbitrales sin negociación previa}

Dentro de la doctrina contractual es indudable que la libertad de configuración interna se restringe, en la medida de que nos encontremos frente a contratos por adhesión o celebrados con arreglo a cláusulas generales de contratación.

En pocas palabras, los contratos por adhesión son aquéllos redactados en su integridad por una sola de las partes, con el ánimo de celebrar en base a estos textos o formularios, un número indefinido de contratos.

Se podría decir que los textos de los contratos por adhesión son invariables. En ellos no hay nada que discutir.

Pero, la libertad contractual o de configuración interna también se ve 
menoscabada en el caso de los contratos celebrados con arreglo a cláusulas generales de contratación.

Como se sabe, en estos contratos hay determinadas cláusulas que se van a incluir de todas maneras en el contrato que se celebra, existiendo alguna flexibilidad, en el sentido de intercambiar algunas cláusulas o de adicionar algunas otras que sean fruto de negociación previa, las mismas que podrían sustituir o complementar algunas cláusulas generales de contratación.

Resulta evidente, entonces, que la cláusula que contenga el convenio arbitral, o sería parte de un contrato por adhesión, o ella misma sería una cláusula general de contratación destinada a integrar un sinnúmero de relaciones contractuales.

\subsubsection{Por el tipo de arbitraje que contempla}

\section{a) De derecho}

La Ley de Arbitraje en actual vigencia, prácticamente, ha entronizado el arbitraje de derecho como fundamental característica del arbitraje en nuestro país.

Es indudable, además, que de la regulación que se hace en particular, el arbitraje de derecho es la regla, y el de conciencia, la excepción.

Incluso, si los convenios arbitrales no señalan la naturaleza del futuro arbitraje, éste será de derecho; lo que equivale a decir que para que sea un convenio arbitral que contemple un arbitraje de conciencia, ello deberá establecerse así, de manera expresa.

\section{b) De conciencia}

De acuerdo a lo señalado en el punto anterior, el arbitraje será de conciencia, en la medida de que las partes así lo hayan establecido expresamente en el convenio arbitral.

\subsubsection{Según contemple o no un arbitraje institucional}

\section{a) Institucional}


Si el convenio arbitral estableciera que el arbitraje será institucional o administrado, ello implicará que el proceso que se inicie en base a este convenio arbitral, deberá ser administrado por algún centro de arbitraje en especial, el mismo que, si fuese el caso, deberá preverse en el propio convenio arbitral.

Es de observar que se trataría de un convenio arbitral patológico, aquél que señalara que el arbitraje deberá ser institucional o administrado por algún centro de arbitraje, pero no señalara cuál; o que señalara el nombre defectuoso de dicho centro; o, incluso, el caso en el cual se contemple que las partes acordarán en el futuro el nombre de dicho centro de arbitraje.

Todos estos convenios arbitrales serían defectuosos o patológicos, en la medida de que no estarían estableciendo reglas claras para la solución de la controversia.

Esto es gravísimo, sobre todo cuando surja el conflicto y se tenga a una parte renuente al arbitraje, que podría, por lo demás, con todo derecho, valerse de las imperfecciones o defectos del propio convenio arbitral para deducir excepciones o cuestiones previas.

En ese sentido, es también patológico el convenio arbitral que, para ser completo, requiere de un nuevo acuerdo de partes, pues a este caso le son aplicables las consideraciones que acabamos de señalar.

b) Ad-Hoc

Resulta claro que si en el convenio arbitral no se estableciera que el arbitraje será institucional o administrado, entonces, será ad-hoc.

\subsubsection{Según si el convenio arbitral contempla un plazo o no}

\section{a) Convenios arbitrales que establecen plazo para la duración del arbitraje}

Existen convenios arbitrales en los que las partes pactan que el proceso arbitral deberá desarrollarse dentro de un plazo máximo total, señalando el número de días naturales o hábiles que deberá durar como máximo el arbitraje.

En estos casos, se debe tener mucho cuidado para no hacer que la labor del 
futuro tribunal arbitral resulte imposible, llevando un proceso arbitral en un plazo tan breve que no permita la debida actuación de las pruebas y el desarrollo de un proceso que revista las mínimas garantías e idoneidad, tanto para las partes como para los árbitros.

Pero, peor aún sería el caso (por cierto, muy frecuente) en que se establezcan plazos muy breves, pero además se haga aplicable al arbitraje, de manera concurrente, el reglamento de un centro de arbitraje que contenga plazos que de por sí rebasen el breve plazo establecido para la duración del arbitraje en el propio convenio arbitral. ${ }^{18}$

Antes de terminar este punto, debemos decir que aquellos convenios arbitrales que hagan aplicable al futuro arbitraje un reglamento arbitral que contenga plazos máximos para el desarrollo del arbitraje, estarán estableciendo indirectamente dicho plazo y, por lo tanto, encuadrarán dentro de este rubro clasificatorio.

\section{b) Convenios arbitrales que no establecen plazo para la duración del arbitraje}

La mayoría de convenios arbitrales no establecen plazo para la duración del arbitraje, ya se trate de convenios que contemplen arbitrajes ad-hoc, o convenios que contemplen arbitrajes administrados institucionales. ${ }^{19}$

En este último caso, ello es así porque, al menos en el Perú, los reglamentos de los centros de arbitraje no establecen plazos de duración máxima para los procesos, limitándose a señalar cuáles serán los plazos (tanto el inicial como la prórroga) con que contará el tribunal arbitral para laudar.

\subsubsection{Según se contemple o no el número de árbitros}

\section{a) Convenios arbitrales que contemplan el número de árbitros}

La experiencia enseña que los convenios arbitrales contemplan el número de árbitros

\footnotetext{
${ }^{18}$ Sobre este particular, ver Castro Zapata, Laura. El convenio arbitral vs. el acta de instalación (o en qué ocasiones puede modificarse lo pactado en el convenio arbitral). Ponencia pronunciada en el Segundo Congreso Internacional de Arbitraje de la Pontificia Universidad Católica del Perú. Lima, 2008, publicada en el vol. 6 de la Biblioteca de Arbitraje del Estudio Mario Castillo Freyre.

${ }^{19}$ Entendiendo, naturalmente, que cuando el reglamento establezca plazos máximos para la duración del arbitraje, estaremos ante el supuesto anteriormente tratado.
} 
que conocerán las controversias que se susciten en el futuro.

Por lo demás, lo usual es que se contemple la presencia de tres árbitros.

Es de señalar que la Ley de Arbitraje establece en su artículo 19 que las partes podrán fijar libremente el número de árbitros que conformen el tribunal arbitral y que, a falta de acuerdo o en caso de duda, serán tres árbitros.

Se aprecia también en la práctica que los tribunales arbitrales unipersonales se contemplan para aquellos casos en donde los volúmenes patrimoniales contratados son bastante reducidos. Es claro también que un tribunal arbitral unipersonal reducirá considerablemente los costos del arbitraje.

Es evidente que conforme a lo dispuesto por el artículo 19 de la Ley de Arbitraje, los tribunales podrían estar integrados por un número distinto de árbitros (2, 4, 6 o 7, por ejemplo). Sin embargo, se trata de situaciones absolutamente inusuales.

\section{b) Convenios arbitrales que no contemplan el número de árbitros}

Aunque la gran mayoría de convenios arbitrales señalan el número de árbitros, un porcentaje reducido de tales convenios omite referirse al particular. Sin embargo, ello no constituye un problema de orden práctico, pues como ha sido mencionado en el análisis del punto anterior, el artículo 19 de la Ley de Arbitraje establece que a falta de acuerdo o, en caso de duda, el tribunal arbitral estará compuesto por tres árbitros. Se trata de una norma de integración y de carácter dispositivo muy útil.

Sin embargo, en materia de contratación estatal, el artículo $189.1^{20}$ del Reglamento de la Ley de Contrataciones con el Estado - Decreto Supremo n. ${ }^{\circ} 350$ 2015-EF, establece que en caso el postor no esté de acuerdo con la propuesta de la entidad o no se pronuncia al respecto en su oferta o si la entidad no cumple con proponer la fórmula en la proforma del contrato, el arbitraje es resuelto por árbitro

\footnotetext{
${ }^{20}$ Artículo 189.- Árbitros

189.1 El arbitraje es resuelto por árbitro único o por un tribunal arbitral conformado por tres (3) árbitros, según el acuerdo de las partes, salvo lo señalado en el artículo 195. La entidad formula una propuesta sobre el número de árbitros que resuelven las controversias en la cláusula de solución de controversias de la proforma de contrato contenida en los documentos del procedimiento de selección. El postor puede consentir o no la propuesta de la entidad al momento de la presentación de su oferta. Si el postor no está de acuerdo con la propuesta de la entidad o no se pronuncia al respecto en su oferta o si la entidad no cumple con proponer la fórmula en la proforma del contrato, el arbitraje es resuelto por árbitro único tratándose de un arbitraje $a d-h o c$ o se determina el número de árbitros correspondiente conforme a las disposiciones del reglamento respectivo en el caso del arbitraje institucional.
} 
único, tratándose de un arbitraje ad-hoc o se determina el número de árbitros correspondiente, conforme a las disposiciones del reglamento respectivo en el caso del arbitraje institucional.

\subsubsection{Según si el convenio arbitral contempla o no el idioma en el que se desarrollará el arbitraje}

\section{a) Que el convenio contemple un idioma especial}

Cuando se trata de un arbitraje nacional, no es frecuente que las partes establezcan en el convenio arbitral cuál será el idioma en que se desarrolle el proceso arbitral. Ello, habida cuenta de que será natural que el proceso se desarrolle en el idioma que ambas partes y, de seguro, los futuros árbitros comparten, es decir, el español.

Sin embargo, el tema adquiere relevancia cuando nos encontramos frente a un arbitraje internacional, en donde no necesariamente las partes provienen de países donde se hable el mismo idioma.

Si ambas partes provienen de países en donde se habla el mismo idioma, probablemente no sea relevante el tema. Pero, si no fuese el caso, sí tendrá relevancia establecer en el convenio arbitral el idioma en que se desarrollará el proceso arbitral.

En estos casos, o se establecerá un tercer idioma distinto al de las partes, o se pactará aquél en que ambas se sientan más cómodas para el desarrollo del proceso.

Es de señalar que no necesariamente los árbitros escogidos podrán conocer dicho idioma, aunque de preferencia deberían conocerlo. Por lo demás, una traducción especializada puede salvar dicha carencia.

\section{b) Que el convenio no contemple un idioma en especial}

En caso el convenio arbitral no contemple un idioma en especial, las partes deberán ponerse de acuerdo sobre el mismo.

En defecto de acuerdo y si resultase aplicable al arbitraje la Ley de Arbitraje peruana, sería de aplicación lo dispuesto por el artículo 36 de la misma, en el sentido de 
que el tribunal arbitral determinará el idioma o los idiomas del arbitraje, atendiendo a las circunstancias del caso.

La referida norma agrega que salvo que en el acuerdo de las partes o en la decisión del tribunal se haya previsto algo distinto, el idioma o los idiomas establecidos se utilizarán en los escritos de las partes, en las audiencias, en los laudos y en las decisiones o comunicaciones del tribunal arbitral.

\subsubsection{Según si el convenio contempla o no la manera de elegir a los árbitros}

\section{a) Si contempla la manera de elegirlos}

La mayoría de convenios arbitrales establecen la manera cómo se elige a los árbitros.

El artículo 23 de la Ley de Arbitraje señala que, en principio, las partes podrán acordar libremente el procedimiento para el nombramiento del árbitro único o de los árbitros, o someterse al procedimiento contenido en un reglamento arbitral, siempre que no se vulnere el principio de igualdad.

En caso se hubiera establecido un mecanismo especial, las partes podrían haber señalado lo dispuesto por la propia Ley de Arbitraje, en lo atinente a la designación del árbitro único (literal a) del artículo 23), o a la designación de un tribunal de tres árbitros (literal b) del artículo 23); pero también podrían haber establecido un mecanismo de designación sui generis que no pase por la designación de árbitros por las propias partes.

Convenios arbitrales en este sentido, son los que establecen, por ejemplo, que los tres árbitros o el árbitro único, necesariamente, serán designados por un determinado centro de arbitraje o por cierta institución o persona natural.

Así también, en algunos casos se aprecia que cuando se establecen mecanismos como éstos, al ser los tres árbitros designados por un tercero, necesariamente se tendrá que recurrir a un mecanismo de sorteo para establecer quién será el presidente del tribunal arbitral.

Sobre este particular la Ley de Arbitraje no establece restricción alguna, salvo el respeto al principio de igualdad. 


\section{b) Si no contempla la manera de elegirlos}

Si éste fuese el caso, regirá de manera supletoria lo establecido por el artículo 23 de la Ley de Arbitraje.

El artículo 23 de la Ley de Arbitraje señala que a falta de acuerdo del procedimiento para el nombramiento del árbitro único o de los árbitros, se aplicarán las siguientes reglas:

a. En caso de árbitro único [...] las partes tendrán un plazo de quince (15) días de recibido el requerimiento de nombramiento para que cumplan con hacerlo.

b. En caso de tres árbitros, cada parte nombrará un árbitro en el plazo de quince (15) días de recibido el requerimiento para que lo haga, y los dos árbitros así $\underline{\text { nombrados}}$, en el plazo de quince días de producida la aceptación del último de los árbitros, nombrarán al tercero, quien presidirá el tribunal. (El subrayado es nuestro).

c. En caso de pluralidad de demandantes o de demandados, cada parte nombrará de común acuerdo a su árbitro, en el plazo de quince (15) días de recibido el requerimiento para que lo hagan. Los dos árbitros así nombrados ${ }^{21}$ en el mismo

${ }^{21}$ ¿Qué entender por árbitros así nombrados? ¿Acaso los árbitros que no son así nombrados no se encontrarían obligados a designar al presidente del tribunal? De acuerdo a lo establecido en los literales b. y c. del artículo 23 de la Ley de Arbitraje, se entiende por árbitros así nombrados a aquéllos que son elegidos directamente por cada parte. En este sentido, serán ellos — los árbitros así nombrados-, quienes deberán elegir al presidente del tribunal.

Sin embargo, nos preguntamos, ¿qué sucede con la obligación de elegir al presidente del tribunal cuando los árbitros no son nombrados así (elegidos directamente por las partes)? ¿Acaso en este supuesto, los árbitros designados — en defecto de las partes - por la Cámara de Comercio del lugar del arbitraje o del lugar de celebración del convenio arbitral, se encontrarían impedidos de elegir al presidente?

Véase que el literal d. del artículo 23 no otorga dicha facultad o no establece dicha obligación, sino que simplemente señala que ante los supuestos en que las partes no designen a los árbitros de la Cámara de Comercio los designará en su defecto, previa solicitud de alguna de las partes.

Imaginemos que las partes acordaron resolver sus discrepancias ante un tribunal arbitral de tres árbitros, y obviaron establecer la manera de elegir a dicho tribunal. Ante este supuesto, por aplicación supletoria del literal b. del artículo 23 de la Ley de Arbitraje, cada parte elige a un árbitro, y luego, los dos árbitros así nombrados, designan al presidente del tribunal. Hasta allí, ningún problema. No cabe duda de que los dos árbitros designados por las partes, tendrán la certeza de cumplir con su obligación de elegir al presidente del tribunal.

Sin embargo, por otro lado, imaginemos — bajo el mismo supuesto — que ninguna de las partes eligió a su árbitro dentro del plazo de los quince días; y días después, una de las partes solicita a la Cámara de Comercio - del lugar del arbitraje o del lugar de celebración del convenio arbitral, cuando no se hubiese pactado el lugar del arbitraje_-, la designación de ambos árbitros. 
plazo, nombrarán al tercero, quien presidirá el tribunal arbitral. (El subrayado es nuestro).

d. Si en alguno de los supuestos anteriores no se llegara a nombrar uno o más árbitros, el nombramiento será efectuado, a solicitud de cualquiera de las partes, por la Cámara de Comercio del lugar del arbitraje o del lugar de celebración del convenio arbitral, cuando no se hubiese pactado el lugar del arbitraje. De no existir una Cámara de comercio en dichos lugares, el nombramiento corresponderá a la Cámara de Comercio de la localidad más cercana.

e. En el arbitraje internacional, el nombramiento a que se refiere el inciso d. de este artículo será efectuado por la Cámara de Comercio del lugar del arbitraje o por la Cámara de Comercio de Lima, cuando no se hubiese pactado el lugar del arbitraje.

Por su parte, en materia de contratación estatal, conforme al artículo $191^{22}$ del Reglamento de la Ley de Contrataciones con el Estado - Decreto Supremo n. ${ }^{\circ}$ 3502015-EF, en aquellos procesos arbitrales ad-hoc en los cuales las partes no hayan pactado la forma en la que se designa a los árbitros o no se hubiesen puesto de acuerdo respecto a la designación del árbitro único o algún árbitro que integre el tribunal arbitral, o los árbitros no se hubieren puesto de acuerdo sobre la designación del

La pregunta que cabe efectuar es ¿esos dos árbitros nombrados por defecto, por la Cámara de Comercio, estarían obligados o facultados para elegir al presidente del tribunal, a pesar de que no fueron designados por las partes (es decir, así nombrados), según el literal b. de la Ley de Arbitraje? O ¿es la Cámara de Comercio que los designó la facultada u obligada a designar?

Creemos que, si bien es cierto que, el literal d. del artículo 23 de la Ley de Arbitraje tiene un vacío, lo cierto es que los árbitros designados por la Cámara deberían elegir al presidente del tribunal dentro del plazo de quince días; caso contrario, el presidente del tribunal debería ser designado también $-\mathrm{y}$ en principio - por la misma Cámara de Comercio.

${ }_{22}$ Modificado por el artículo 1 del Decreto Supremo n. ${ }^{\circ}$ 056-2017-EF, publicado el 19 de marzo de 2017, el mismo que entró en vigencia a los quince (15) días contados a partir de su publicación en el diario oficial El Peruano.

Artículo 191.- Designación Residual de Árbitros En aquellos procesos arbitrales ad-hoc en los cuales las partes no hayan pactado la forma en la que se designa a los árbitros o no se hayan puesto de acuerdo respecto a la designación del árbitro único o algún árbitro que integre el Tribunal Arbitral, o los árbitros no se hayan puesto de acuerdo sobre la designación del presidente del Tribunal Arbitral, cuando corresponda, cualquiera de las partes puede solicitar al OSCE la designación residual, la que se efectuará a través de una asignación aleatoria por medios electrónicos, de acuerdo a los plazos y procedimiento previstos en la Directiva correspondiente. En caso la solicitud de designación residual no se presente dentro del plazo respectivo, la solicitud de arbitraje queda sin efecto automáticamente. Las designaciones residuales efectuadas por el OSCE se realizan de su nómina de Árbitros para Designación Residual, y son definitivas e inimpugnables. Los procedimientos de inscripción y renovación de árbitros en dicha nómina se realizan conforme a lo establecido en la respectiva Directiva. 
presidente del tribunal arbitral, cuando corresponda, cualquiera de las partes solicitar al OSCE la designación residual, la misma que se efectuará a través de una asignación aleatoria por medios electrónicos, de acuerdo a los plazos y procedimientos previstos en la directiva correspondiente.

\subsubsection{Según si el convenio establece o no los requisitos que deben reunir los} árbitros

\section{a) Si el convenio establece los requisitos}

No resulta práctica usual que los convenios arbitrales establezcan determinados requisitos que deban reunir los árbitros que integrarán el tribunal que conocerá las controversias que se susciten entre las partes.

En este caso, si al arbitraje resultara de aplicación la ley peruana, será claro que, en caso estemos en presencia de un arbitraje nacional y de derecho, los tres árbitros deberán ser abogados; en tanto si el arbitraje fuese de conciencia, tales árbitros podrán ser de profesiones u oficios diferentes.

Cabe señalar que si se tratase de un arbitraje regulado por la Ley de Contrataciones del Estado y su reglamento, a pesar de ser un arbitraje de derecho, los árbitros de parte podrán ser o no abogados, debiendo el presidente tener necesariamente esta profesión.

En este tipo de arbitrajes, si se tratara de árbitro único, éste siempre deberá ser abogado.

Además, es de recordar que la Ley de Contrataciones del Estado y su reglamento establecen determinados requisitos referidos a la experiencia de los árbitros, tal como se aprecia en las normas que citamos y explicamos a continuación.

El artículo $45.6^{23}$ de la Ley de Contrataciones con el Estado - Ley n. ${ }^{\circ} 30225$, exige que el árbitro único y el presidente del tribunal sean abogados y que además

\footnotetext{
${ }^{23} 45.6 \mathrm{El}$ arbitraje es de derecho y resuelto por árbitro único o tribunal arbitral integrado por tres miembros. El árbitro único y el presidente del tribunal arbitran deben ser necesariamente abogados, que cuenten con especialización acreditada en derecho administrativo, arbitraje y contrataciones con el Estado. Los demás integrantes del tribunal arbitral pueden ser expertos o profesionales en otras materias, debiendo necesariamente tener conocimiento en contrataciones con el Estado.
} 
cuenten con tres especialidades acreditadas en: (i) derecho administrativo, (ii) arbitraje, y (iii) contrataciones con el Estado.

Esto es, que la exigencia de la triple especialidad recae solamente sobre el árbitro único y el presidente del tribunal, sin importar si fueron designados directamente por las partes o por el OSCE, toda vez que el referido artículo 45.6 precisa que los demás integrantes del tribunal pueden ser expertos o profesionales en otras materias, debiendo necesariamente tener conociiento en contrataciones con el Estado.

Esta última afirmación nos lleva a concluir en que los árbitros, cuando son designados por las partes, deberán cumplir — por lo menos - con el requisito de ser profesionales, sin importar su experiencia en materia arbitral y/o derecho administrativo.

En realidad, tal afirmación es correcta cuando se trata de árbitros designados por las partes (árbitros de parte). Sin embargo, recordemos que cuando el OSCE es quien designa por defecto de las partes (designación residual), ${ }^{24}$ dichos árbitros deben ser elegidos de su Registro de Árbitros.

En ese sentido, la Directiva n. ${ }^{\circ}$ 004-2006-CONSUCODE/PRE, ${ }^{25}$ en concordancia con el numeral 16 del TUPA del OSCE ${ }^{26}$ establece como requisito haber aprobado el Curso de Formación de Árbitros a cargo del OSCE, o en su defecto, contar con una capacitación no menor de ciento veinte (120) horas académicas en arbitraje.

Además, acreditar como mínimo, uno de los siguientes requisitos:

a) Certificado(s) de Diplomado(s) expedido(s) por Universidades que acredite(n) especialización en contrataciones con el Estado.

b) Documentos que acrediten experiencia en derecho administrativo no menor de cinco (5) años.

\footnotetext{
Asimismo, para desempeñarse como árbitro, en el caso de los arbitraje $a d$-hoc, se requiere estar inscrito en el Registro Nacional de Árbitros administrado por el Organismo Supervisor de las Contrataciones del Estado (OSCE), conforme a los requisitos y condiciones establecidos en la directiva que apruebe dicha entidad para tal efecto. El registro es de aprobación automática, sujeto a fiscalización posterior.

${ }^{24}$ Directiva n. ${ }^{\circ}$ 019-2012-OSCE/CD (hoy OSCE), que regula el procedimiento de designación residual de árbitros al amparo de la normativa de contrataciones del Estado.

${ }^{25}$ Que regula los requisitos y procedimientos para la incorporación de árbitros y conciliadores en el Registro de neutrales del Consucode, aprobada por Resolución n. ${ }^{\circ}$ 107-2006-CONSUCODE/PRE, del 1 de marzo de 2006.

${ }^{26}$ Inscripción de Árbitros Nacionales en el SNA-OSCE del Texto Único de Procedimientos Administrativos del OSCE.
} 
c) Documentos que acrediten experiencia en arbitraje actuando como árbitro, abogado o secretario arbitral, no menor a cinco (5) años.

d) Documentos que acrediten experiencia en contrataciones públicas mediante el ejercicio privado de la profesión, no menor de cinco (5) años.

e) Documentos que acrediten experiencia en contrataciones públicas mediante el ejercicio de la función pública, no menor de cinco (5) años.

f) Certificado(s) de Diplomado(s) expedido(s) por Universidades que acredite(n) especialización en arbitraje.

g) Certificado(s) de Diplomado(s) expedido(s) por Universidades que acredite(n) especialización en derecho administrativo.

En otros convenios arbitrales, ya se trate de arbitrajes nacionales o internacionales, sí se establecen los requisitos que deberán reunir los árbitros.

Estos requisitos, fundamentalmente, están referidos a años de experiencia en el ejercicio de la profesión, especialidad acreditada en alguna rama de la profesión que se ejerza, nacionalidad y demás características que puedan garantizar a las partes determinadas condiciones mínimas de idoneidad y de categoría, conforme a la importancia del contrato en el que se inserta el convenio arbitral, o de los volúmenes patrimoniales que se prevé sean controvertidos.

\section{b) Si el convenio no establece los requisitos}

No vamos a ingresar al desarrollo de este punto, pues el mismo se explica por oposición a la lectura del anterior.

\subsubsection{Según si el convenio establece o no criterios para los honorarios del tribunal arbitral}

\section{a) Si el convenio establece dichos criterios}

Resulta poco usual que los convenios arbitrales incluyan estipulaciones sobre los honorarios de los árbitros, al menos, directamente. 
Decimos esto, pues, si el convenio arbitral estableciese que el arbitraje será uno institucional o administrado, éste se regirá por el reglamento arbitral del respectivo centro de arbitraje y, por ende, le serán aplicables las tarifas vigentes de dicho centro.

En este caso, los árbitros no tendrán libertad alguna para la fijación de sus honorarios y los del secretario arbitral, pues éste será un funcionario del respectivo centro de arbitraje.

Asimismo, serán aplicables al caso las tasas o tarifas administrativas que cobrará el centro de arbitraje.

Sin embargo, cabe la posibilidad de que las partes establezcan en el convenio arbitral alguna disposición relativa a los honorarios de los árbitros y del secretario arbitral, tratándose de arbitrajes ad-hoc.

En los pocos casos en que ello ocurre, se suele observar que se pacte la aplicación supletoria de las tarifas de algún centro de arbitraje en especial, no siendo, sin embargo, aplicable al caso el reglamento de arbitraje de ese centro, ni tampoco se trata de un arbitraje administrado por el mismo.

Sin duda, el establecimiento de tales referencias tiene por objeto hacer más o menos predecibles los costos del arbitraje, en la medida de que los árbitros no quedarán en libertad para establecer sus honorarios.

\section{b) Si el convenio arbitral no establece dichos criterios}

En la mayoría de convenios arbitrales que contemplan arbitrajes ad-hoc, no se establece disposición alguna sobre los honorarios de los árbitros, lo que implica que serán los tribunales arbitrales los encargados de establecer la cuantía de dichos honorarios, la misma que usualmente se fija en razón de los montos controvertidos y de la dificultad que implica el conocimiento y desarrollo del proceso.

En los arbitrajes ad-hoc relativos a contrataciones del Estado, el Reglamento de la Ley de Contrataciones del Estado establece que los árbitros deben fijar sus honorarios profesionales y de la secretaría arbitral o gastos administrativos aplicando la tabla de gastos arbitrales de cualquier institución arbitral acreditada. ${ }^{27}$

\footnotetext{
${ }^{27}$ Artículo 196.- Gastos arbitrales

196.1 En el arbitraje ad-hoc, los árbitros deben fijar sus honorarios profesionales y de la secretaría
} 


\subsubsection{Según si el convenio arbitral establece o no cuál de las partes debe asumir el pago de los costos del arbitraje}

\section{a) Si el convenio arbitral establece quién debe asumirlos}

Son pocos los casos en los cuales el convenio arbitral establece qué parte debe asumir los costos del arbitraje.

Dentro del escaso porcentaje de convenios arbitrales que se refieren al tema, la mayoría de ellos hace alusión a que tales costos deberán ser asumidos por las partes en iguales proporciones.

Sin embargo, un número mínimo de convenios arbitrales suele establecer que los costos del arbitraje serán asumidos por completo por la parte demandante, debiéndose entender en este caso que quien demande asumirá los costos que implique las pretensiones de la demanda, y quien reconvenga (parte contrademandante) deberá asumir los costos que ocasionen las pretensiones contenidas en la reconvención.

La Ley de Arbitraje establece la mayor libertad para estos efectos. Sin embargo, no es recomendable cargar todos los costos del proceso a la parte demandante, en la medida de que ello podría hacer muy onerosa su participación en el arbitraje y tener que esperar la eventual ejecución de un laudo, en el que resulte victoriosa para obtener la restitución de tales montos.

\section{b) Si el convenio arbitral no establece quién debe asumirlos}

En la generalidad de convenios arbitrales, no se establece disposición alguna sobre quién debe asumir los costos del arbitraje.

arbitral o gastos administrativos aplicando la tabla de gastos arbitrales de cualquier institución arbitral acreditada.

196.2 En caso de renuncia, recusación de árbitro declarada fundada, anuencia de la contraparte en la recusación, remoción de árbitro y los demás supuestos regulados por el OSCE para tal efecto, y cuando no se trate de un arbitraje institucional, cualquier discrepancia que surja entre las partes y los árbitros, respecto de la devolución de honorarios, debe ser resuelta, a pedido de parte, por el OSCE. La decisión que tome el OSCE al respecto es definitiva e inimpugnable.

Cualquier pacto respecto de la no devolución de honorarios se tiene por no puesto, no pudiéndose acordar en contrario. 
En ese sentido, la mayoría de reglamentos de los diversos centros de arbitraje en el Perú, así como las reglas contenidas en las actas de instalación de los arbitrajes ad-hoc, establecen que las partes deberán asumir en proporciones iguales los gastos que ocasione el arbitraje.

Naturalmente, ocurre con frecuencia que la parte demandada (y no reconviniente) se niegue a asumir la parte de costos arbitrales que le corresponde; ello, con el objeto de hacer más difícil la defensa del demandante. Sin embargo, no vamos a ahondar sobre el particular, en la medida de que este tema no constituye objeto de nuestro estudio.

\subsubsection{Según si el convenio arbitral establece o no la sede del arbitraje}

a) Cuando el convenio establece la sede

No habrá problemas cuando se trate de un arbitraje institucional o administrado, ya que, conforme al reglamento arbitral aplicable, la sede del arbitraje será aquélla donde se encuentre dicho centro de arbitraje.

El problema se presentará cuando estemos en presencia de arbitrajes ad-hoc, en los cuales el tribunal arbitral será el competente para determinar la sede.

No cabe duda de que si las partes y los árbitros residen en una misma ciudad, la sede estará ubicada en esa ciudad.

El problema se complica cuando las partes tienen sus establecimientos en ciudades diferentes $\mathrm{y}$, probablemente, los árbitros también, casos en los cuales, el tribunal arbitral tendrá que resolver en función de las circunstancias que se aprecien como más convenientes para todos, ya sea en función de facilidades de transporte, costos o idoneidad de los servicios que se pueden obtener en las ciudades en juego, así como la seguridad jurídica necesaria para el desarrollo del proceso.

\section{b) Cuando el convenio no establece la sede}

No vamos a desarrollar este punto, en función de lo ya expresado en el rubro anterior. 


\section{CAPÍTULO III: COMENTARIOS SOBRE LA FORMALIDAD DEL CONVENIO ARBITRAL}

\subsection{Antecedentes}

El Código de Procedimientos Civil de 1912, ${ }^{65}$ el texto original del Código Civil de 1984, ${ }^{66}$ la Ley General de Arbitraje de 1992 (Decreto Ley n. ${ }^{\circ} 25935$ ), ${ }^{67}$ la Ley General de Arbitraje n. 26572 de $1996^{68}$ y el Decreto Legislativo n. ${ }^{\circ} 1071$ del año $2008,{ }^{69}$ han

${ }^{65}$ Artículo 552.- «El compromiso ha de formalizarse, bajo pena de nulidad, en escritura pública; pero si hay juicio pendiente, bastará que se consigne en recurso presentado al juez, con legalización de firmas». 66 Artículo 1910.- «El compromiso arbitral debe celebrarse por escrito, bajo sanción de nulidad. Si hay un juicio pendiente, bastará que se consigne en recurso presentado al juez, con firmas certificadas por el secretario de la causa».

${ }^{67}$ Artículo 5.- «El convenio arbitral se celebra por escrito, bajo sanción de nulidad. Puede estipularse como cláusula incorporada a un contrato o convenio principal, o como acuerdo independiente. Se entiende que el convenio se ha formalizado por escrito no solamente cuando está contenido en documento único suscrito por las partes, sino también cuando resulta de intercambio de cartas o de cualquier otro medio de comunicación o correspondencia que inequívocamente deje constancia documental de la voluntad de las partes de someterse a arbitraje».

${ }^{68}$ Artículo 10.- «Forma del convenio arbitral

El convenio arbitral se celebra por escrito, bajo sanción de nulidad. Podrá adoptar la forma de una cláusula incluida en un contrato o la forma de un acuerdo independiente. Se entiende que el convenio arbitral se ha formalizado por escrito no solamente cuando está contenido en documento único suscrito por las partes, sino también cuando resulta del intercambio de cartas o de cualquier otro medio de comunicación o correspondencia que inequívocamente deje constancia documental de la voluntad de las partes de someterse a arbitraje. Se entiende además que el convenio arbitral se ha formalizado por escrito cuando a pesar de no existir acuerdo previo, por iniciativa de una de las partes involucradas se somete una controversia a la decisión de uno o más árbitros que aceptan resolver el conflicto, mediando asentimiento posterior de la otra u otras partes a dicho sometimiento. Se entenderá que hay asentimiento cuando, notificada la parte contraria de la iniciativa de quien promovió la intervención de él o los árbitros, se apersona al procedimiento arbitral sin objetar dicha intervención».

${ }^{69}$ Artículo 13.- «Contenido y forma del convenio arbitral

$[\ldots]$

2. El convenio arbitral deberá constar por escrito. Podrá adoptar la forma de una cláusula incluida en un contrato o la forma de un acuerdo independiente.

3. Se entenderá que el convenio es escrito cuando quede constancia de su contenido en cualquier forma, ya sea que el acuerdo de arbitraje o contrato se haya concentrado mediante la ejecución de ciertos actos o por cualquier otro medio.

4. Se entenderá que el convenio arbitral consta por escrito cuando se cursa una comunicación electrónica y la información en ella consignada es accesible para su ulterior consulta. Por "comunicación electrónica" se entenderá toda comunicación que las partes hagan por medio de mensajes de datos. Por "mensaje de datos" se entenderá la información generada, enviada, recibida o archivada por medios electrónicos, magnéticos, ópticos o similares, como pudieran ser, entre otros, el intercambio electrónico de datos, el correo electrónico, el telegrama, el télex o el telefax.

5. Se entenderá además que el convenio arbitral es escrito cuando esté consignado en un intercambio de escritos de demanda y contestación en los que la existencia de un acuerdo sea afirmada por una parte, sin ser negada por la otra. 
establecido invariablemente que el convenio arbitral debe revestir formalidad escrita.

Sin embargo, es nuestra impresión que con el paso de los años y las leyes, se ha ido relajando el concepto de formalidad escrita, de modo tal que si bien el mismo permanece como regla, su contenido y alcances han variado sustancialmente.

\subsection{La formalidad del convenio arbitral en el Decreto Legislativo $n .^{\circ} 1071$}

La formalidad del convenio arbitral se encuentra regulada en el artículo 13 de la actual Ley de Arbitraje, Decreto Legislativo n. ${ }^{\circ}$ 1071, norma de texto siguiente:

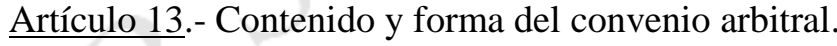

1. El convenio arbitral es un acuerdo por el que las partes deciden someter a arbitraje todas las controversias o ciertas controversias que hayan surgido o que puedan surgir entre ellas respecto de una determinada relación jurídica contractual o de otra naturaleza.

2. El convenio arbitral deberá constar por escrito. Podrá adoptar la forma de una cláusula incluida en un contrato o la forma de un acuerdo independiente.

3. Se entenderá que el convenio arbitral es escrito cuando quede constancia de su contenido en cualquier forma, ya sea que el acuerdo de arbitraje o contrato se haya concretado mediante la ejecución de ciertos actos o por cualquier otro medio.

4. Se entenderá que el convenio arbitral consta por escrito cuando se cursa una comunicación electrónica y la información en ella consignada es accesible para su ulterior consulta. Por «comunicación electrónica» se entenderá toda comunicación que las partes hagan por medio de mensajes de datos. Por «mensaje de datos» se entenderá la información generada, enviada, recibida o archivada por medios electrónicos, magnéticos, ópticos o similares, como pudieran ser, entre otros, el intercambio electrónico de datos, el correo electrónico, el telegrama, el télex o el telefax.

5. Se entenderá además que el convenio arbitral es escrito cuando esté consignado en un intercambio de escritos de demanda y contestación en los que la existencia de

6. La referencia hecha en un contrato a un documento que contenga una cláusula de arbitraje constituye un convenio arbitral por escrito, siempre que dicha referencia implique que esa cláusula forma parte del contrato.

7. Cuando el arbitraje fuere internacional, el convenio arbitral será válido y la controversia será susceptible de arbitraje, si cumplen los requisitos establecidos por las normas jurídicas elegidas por las partes para regir el convenio arbitral, o por las normas jurídicas aplicables al fondo de la controversia, o por el Derecho peruano». 
un acuerdo sea afirmada por una parte, sin ser negada por la otra.

6. La referencia hecha en un contrato a un documento que contenga una cláusula de arbitraje constituye un convenio arbitral por escrito, siempre que dicha referencia implique que esa cláusula forma parte del contrato.

7. Cuando el arbitraje fuere internacional, el convenio arbitral será válido y la controversia será susceptible de arbitraje, si cumplen los requisitos establecidos por las normas jurídicas elegidas por las partes para regir el convenio arbitral, o por las normas jurídicas aplicables al fondo de la controversia, o por el derecho peruano.

Como se puede apreciar, el citado artículo cuenta con siete incisos, el primero de los cuales se ocupa de definir qué es el convenio arbitral, en tanto los seis restantes abordan el tema de la formalidad.

En el capítulo primero de este trabajo ya hemos hecho referencia al inciso 1 de esta norma, razón por la cual el análisis de este artículo en el presente capítulo se centra en los incisos 2 a 7 del artículo 13.

\subsubsection{La formalidad escrita}

El inciso 2 del artículo 13 es enfático cuando establece que el convenio arbitral deberá constar por escrito.

Como hemos señalado, tal es la regla y el artículo 13 en verdad no llega a admitir de manera expresa ninguna excepción, más allá de que equipara una serie de otras formalidades a la formalidad escrita.

No debemos olvidar que tradicionalmente se ha entendido por formalidad escrita, aquélla que imponían los medios de contratación tradicional, vale decir, que el convenio arbitral fuese suscrito por ambas partes en documento físico escrito.

Por lo demás, ésta ha sido siempre la manera cómo se han celebrado los contratos importantes y no cabe duda de que aquellos contratos que contienen convenios arbitrales son, por lo general, de los que imponen una ejecución de prestaciones a futuro $\mathrm{y}$, generalmente, dichas prestaciones implican valores patrimoniales apreciables o de importancia, por lo menos, a consideración de las partes que celebran tal convenio.

Naturalmente que este mecanismo tradicional de contratación no excluye el 
hecho de que pueda ser contemplado por una serie de otras maneras de contratar, que imponen algunas variantes que luego serán objeto de estudio en este trabajo.

Dentro del análisis del inciso 1 del artículo 13, es importante subrayar que la norma establece también que el convenio arbitral podrá adoptar la forma de una cláusula incluida en un contrato, o la de un acuerdo independiente. Sin embargo, no vamos a ahondar sobre este tema, pues él ya ha sido objeto de estudio.

\subsubsection{Ejecución contractual asimilada a la formalidad escrita}

Como se recuerda, el inciso 2 del artículo 13 de la Ley de Arbitraje, establece que se entenderá que el convenio arbitral es escrito cuando quede constancia de su contenido en cualquier forma, ya sea que el acuerdo de arbitraje o contrato se haya concretado mediante la ejecución de ciertos actos o por cualquier otro medio.

Lo antes expresado concuerda plenamente con lo dispuesto por el artículo 1380 del Código Civil, precepto que establece que:

Artículo 1380.- Cuando a solicitud del oferente o por naturaleza de la operación o según los usos, la presentación a cargo del aceptante haya de ejecutarse, sin respuesta previa, el contrato queda concluido en el momento y lugar en que comenzó la ejecución. [...].

Como sabe, en la práctica existen situaciones en las cuales los contratos se formalizan con la rigurosa ejecución de un documento por las partes que lo celebran.

En otros casos, en cambio, dada la celeridad de los negocios y de la vida moderna, existen contratos que se celebran sin esperar una respuesta previa del destinatario de la oferta, habida cuenta de que existe la premura de que tales contratos se comiencen a ejecutar de inmediato.

En tales casos, podría ocurrir que en verdad no nos encontremos frente a un documento final que haya sido suscrito por ambas partes, sino frente a un documento que haya sido remitido por el oferente al destinatario de la oferta y que éste formalmente no haya aceptado $\mathrm{y}$, mucho menos, firmado conjuntamente con la otra parte.

Pero, podría darse el caso en el cual el convenio arbitral no conste en un documento firmado por alguien, pues las partes ya hayan empezado a ejecutar el contrato. 
En este caso, lo que correspondería preguntarse es si nos encontramos frente a un convenio arbitral por escrito.

Estimamos que la respuesta evidente es que no, pues resulta claro que el convenio arbitral no consta por escrito.

Y no consta por escrito, ya que el documento en el cual se encontraba inserto el convenio arbitral, o si se trataba de un convenio independiente, el documento en el que constaba dicho convenio, nunca fue objeto de suscripción por las partes, de modo tal que queda claro que el convenio nunca constó por escrito.

Lo que también queda claro es que la Ley de Arbitraje otorga equivalencia de forma escrita a una situación de esta naturaleza, no siéndolo en la realidad.

La ley otorga relevancia a aquellos casos en los cuales las partes, al fin de cuentas, han ejecutado en la práctica el convenio arbitral, a pesar de que el mismo no se haya suscrito jamás.

En verdad, podríamos encontrarnos ante una situación en la cual el convenio hubiera sido concertado incluso de manera verbal, con lo cual se resquebraja el principio de que el convenio arbitral debe constar necesariamente por escrito.

En ese sentido, lo que establece el inciso 3 es simplemente una ficción, asimilando su contenido a la formalidad escrita.

\subsubsection{Comunicaciones electrónicas}

Como señalamos al analizar la regla general relativa a la formalidad del convenio arbitral, siempre se ha partido de la idea de que el convenio debía constar en un documento, el mismo que a la vez fuese suscrito por ambas partes.

No obstante, la contratación contemporánea determina que en infinidad de casos los contratantes no se encuentren presentes en el mismo lugar, lo que conduce al problema relativo a la contratación entre ausentes, o, si se quiere denominar con más propiedad, a la contratación entre personas que no se encuentran en comunicación directa.

No cabe duda, tampoco, de que desde hace mucho tiempo este mecanismo de contratación ha venido siendo empleado por las empresas, primero con el telegrama y 
con el télex, y luego con la contratación facsimilar.

No obstante, todos esos medios de contratación, usuales en otros tiempos, han dejado de tener vigencia y, en la actualidad, el medio electrónico que es empleado de manera regular para el envío de documentos entre personas que no se encuentran en comunicación inmediata, es el correo electrónico, a través del Internet.

De esta forma, es usual que el intercambio de documentos por e-mails, determine que los contratos se celebren con el solo intercambio de los mismos, aplicando para tal efecto las reglas establecidas en el Código Civil, en los artículos 1373 y 1374 , que regulan el particular.

En ese sentido, quedando claro que las personas no suscribirían el mismo documento, entendido como un único documento físico en su forma original, quedará claro también que el intercambio de documentos, remitidos como declaración de voluntad de cada una de las partes, que determine la existencia de consentimiento, hará que el contrato conste, precisamente, en el intercambio de dichos documentos electrónicos, de modo tal que ni las firmas constarán en un solo documento, e incluso podría darse el caso en que los documentos remitidos por dichas partes, ni siquiera estén firmados, pues ello, en verdad, no resulta necesario en tiempos modernos, y nótese, además, que ni siquiera nos estamos refiriendo a la firma electrónica, pues tranquilamente puede prescindirse de ella.

Ahora bien, podríamos preguntar, en este caso, si el intercambio de documentos electrónicos, en realidad hace que el contrato conste por escrito.

Pensamos que sí, pues el concepto de documento escrito también se extiende al documento electrónico.

En ese sentido, sería innegable que un contrato redactado en documento electrónico, tendría la forma escrita, pues no podríamos restringir esta formalidad, ya que el hecho de que no haya sido impreso en formato papel, no le resta la consideración de haber sido redactado por escrito.

Para todos esos casos, el inciso 4 del artículo 13 de la Ley de Arbitraje, también estima que nos encontramos frente a una formalidad escrita. 


\subsubsection{Demanda y contestación}

El inciso 5 del artículo 13 señala que se entenderá, además, que el convenio arbitral es escrito cuando esté consignado en un intercambio de escritos de demanda y contestación en los que la existencia de un acuerdo sea afirmada por una parte, sin ser negada por la otra.

Éste sería el caso en el cual el inicio de un proceso arbitral se efectúe con mención de la futura parte demandante, de la existencia de un convenio arbitral, cuyo texto impreso no adjunta, pero al cual se refiere en detalle al momento de presentar dicha petición de arbitraje.

En tal sentido, si la contestación a dicha petición de arbitraje, fuera pacífica en lo que respecta a la existencia del convenio arbitral, no cabrá duda de que el referido convenio arbitral tendrá existencia, habida cuenta de que la futura parte demandada no habría puesto reparos a lo expresado por quien solicita el arbitraje.

Dentro de tal orden de ideas, es necesario distinguir dos situaciones diferentes, que podrían estar comprendidas en el supuesto bajo análisis:

La primera de ellas consistiría en que la parte que solicita el arbitraje sí haya celebrado un convenio arbitral por escrito con la futura parte demandante y el hecho de no haber acompañado el texto a la petición de arbitraje, no implicará que el mismo no se haya celebrado por escrito.

En ese sentido, la futura parte demandante, no podría negar la existencia del convenio arbitral y su contenido, en razón de que el convenio arbitral sí existe.

La segunda situación que, propiamente, resulta ser el objeto central del inciso bajo comentario y es aquél en el cual el convenio arbitral no haya preexistido a la solicitud de arbitraje, y que, precisamente, con dicha solicitud de arbitraje, se plantee celebrar el convenio. $^{70}$

\footnotetext{
${ }^{70}$ Cabe señalar que en realidad, la Ley de Arbitraje se equivoca cuando hace referencia al intercambio de escritos de demanda y contestación. Debería referirse a la solicitud de arbitraje y contestación a dicha solicitud; toda vez que es en la solicitud de arbitraje, que la futura parte demandante manifiesta su intención de resolver una determinada controversia a través del arbitraje, designando —inclusive — al árbitro correspondiente. Así, en la contestación a la solicitud de arbitraje, la futura parte demandada, tendrá la oportunidad de negar u oponerse al arbitraje por inexistencia de convenio arbitral. Caso contrario, si la futura parte demandada, contestara la solicitud de arbitraje sin negar la existencia del acuerdo arbitral afirmado por su futura contraparte, se entenderá que el convenio arbitral existe y por escrito. Tómese nota, además, de que la Ley de Arbitraje, salvo acuerdo distinto entre las partes, establece que el arbitraje se inicia con la recepción de la solicitud para someter una controversia a
} 
Si la destinataria de la solicitud de arbitraje contestara a la misma con su aceptación a la jurisdicción arbitral, no cabe duda de que ese intercambio de comunicaciones implicaría la aceptación del convenio arbitral, en virtud de la aplicación de los principios generales sobre consentimiento, regulados en nuestro Código Civil.

\subsubsection{Convenio arbitral por referencia}

En el inciso 6 del artículo 13 de la Ley de Arbitraje se establece que la referencia hecha en un contrato a un documento que contenga una cláusula de arbitraje, constituye un convenio arbitral por escrito, siempre que dicha referencia implique que esa cláusula forma parte del contrato.

Se trata del caso de los convenios celebrados por referencia.

El convenio arbitral por referencia no está incluido en el contrato cuyas controversias está destinado a solucionar.

En estos casos, el convenio arbitral se encuentra incluido en otro contrato distinto del que forma parte, o el convenio arbitral consta como única cláusula de un contrato independiente.

Dentro de tal orden de ideas, se denomina convenio arbitral por referencia, pues aquel contrato que no contiene convenio arbitral, incluye una cláusula que haga mención a que las controversias surgidas en relación a este contrato, se solucionarán en razón a lo establecido en alguno de los otros contratos a que hemos hecho mención, contratos que sí contienen un convenio arbitral.

Podría ser el caso, por ejemplo, de un contrato de reaseguro que no desarrolle específicamente una cláusula relativa a la solución de controversias entre la compañía de seguros y el reasegurador, pero que establezca que las controversias entre estas empresas se solucionarán conforme a lo dispuesto en el contrato de seguro, que se está reasegurando. Éste sería un típico convenio arbitral por referencia.

Teóricamente, los convenios arbitrales por referencia no deberían merecer objeciones, pues en estricta teoría contractual quedaría muy claro que las partes, si bien por referencia, habrían celebrado un convenio arbitral.

arbitraje. 
No obstante, y a pesar de no ser objeto de estudio en este trabajo, pues ello rebasaría los límites del mismo, debemos señalar que algunos derechos nacionales y un sector de la doctrina objeta la validez de los convenios arbitrales por referencia, en la medida en que a través de ellos no se hace expresa renuncia a la jurisdicción ordinaria, lo que sí ocurre cuando directamente se celebra un convenio arbitral.

A nuestro juicio, tales doctrinas son equivocadas, ya que si las partes que celebran el convenio arbitral por referencia están bien instruidas y conocen en detalle el contenido del convenio arbitral al que están haciendo referencia (es decir, que están adoptando para su propio contrato), eso significa que no existe inconveniente conceptual alguno para estimar que al adoptarlo de esa forma, también han hecho renuncia a la jurisdicción ordinaria, tal como si se trata de un convenio arbitral celebrado de manera directa y no por referencia.

\subsubsection{Convenio arbitral en arbitraje internacional}

El inciso 7 del artículo 13 de la Ley de Arbitraje establece que cuando el arbitraje fuere internacional, el convenio arbitral será válido y la controversia será susceptible de arbitraje, si se cumplen los requisitos establecidos por las normas jurídicas elegidas por las partes para regir el convenio arbitral, o por las normas jurídicas aplicables al fondo de la controversia, o por el Derecho peruano.

Sobre este particular, cabe decir que esta norma se refiere no sólo a la formalidad del convenio arbitral, sino también a la materia arbitrable.

En ese sentido, se determinará si la materia es arbitrable como si el convenio es válido en cuanto a su formalidad, conforme a lo que dispongan las normas jurídicas elegidas por las partes para regir el convenio arbitral, o por las normas jurídicas aplicables al fondo de la controversia, o por el Derecho peruano. 


\section{CONCLUSIONES}

- El convenio arbitral es un acuerdo entre partes, quienes se obligan (basadas en la autonomía privada) a someter sus conflictos a la decisión de un tribunal arbitral. En ese sentido, el convenio arbitral generalmente (excepción hecha del arbitraje testamentario) es un contrato con prestaciones recíprocas, en donde las partes se obligan a lo mismo, a saber: resolver la disputa en vía arbitral. De esta manera, la prestación de una será — en caso de presentarse las controversias - activar el mecanismo del convenio arbitral, y la contraprestación será, aceptar, continuar y proseguir con el mecanismo activado por la primera, a menos que escape de los alcances del convenio arbitral.

- A pesar de que en los contratos con prestaciones recíprocas, las partes tienen intereses opuestos al momento de su celebración, en el convenio arbitral no sucede esto, toda vez que las partes se obligan a lo mismo (resolver la disputa en vía arbitral) y, por lo tanto, los intereses opuestos, que normalmente existen al celebrar los contratos, no son perceptibles al momento de la celebración del convenio arbitral, porque no sabemos cuáles son las controversias que van a surgir. Es más, ni siquiera se sabe si existirán controversias. Ellas recién se conocerán en el futuro.

- Así, el convenio arbitral podría ser un contrato, que con la autonomía que tiene, nunca se ejecute. De tal manera que, a diferencia del resto de contratos, es muy posible que este convenio nunca se ejecute; y ello sería lo ideal, porque el Derecho quisiera, que nunca se presente la controversia.

- El convenio arbitral puede revestir la forma de una cláusula arbitral, cuando constituye parte de un contrato mayor, o como contrato independiente, cuando es celebrado en documento aparte, ante su inexistencia; pudiendo celebrarse antes del surgimiento del conflicto (situación ideal), o luego de suscitada la controversia. Dentro de este último supuesto, podríamos encontrar como justificación, el interés de las partes por resolver de manera rápida la controversia, la presencia de 
convenios arbitrales insuficientes o, bien porque la controversia se derive de un supuesto de responsabilidad extracontractual.

- Siendo usual que los convenios arbitrales provengan de relaciones contractuales, es también usual que éstas estén conformadas por sólo dos partes (convenio arbitral bilateral); sin embargo, nada obsta para que el convenio arbitral pueda ser plurilateral. Lamentablemente, hay que tener presente que, en algunos casos, los contratos plurilaterales presentarán como inconveniente, al inicio del arbitraje, el tema relativo al nombramiento de los árbitros, en la medida de que, salvo disposición diversa del propio convenio arbitral, no es que cada parte contractual vaya a nombrar un árbitro, sino que los árbitros de parte deberán ser nombrados, uno, por las partes contractuales que conformen la parte demandante, y el otro, por las partes contractuales que conformen la parte demandada; siendo evidente que ambos árbitros elegirán al presidente del tribunal.

- Por excepción, el «convenio arbitral» puede ser celebrado por una sola parte. Tal es el caso del arbitraje testamentario, el mismo que nace de una «cláusula arbitral» contenida en el testamento, y no de un acuerdo de partes. Su alcance dependerá exclusivamente - de los términos establecidos por el testador.

- En principio, es regla general dentro del Derecho peruano, conforme lo establece el artículo 1363 del Código Civil, que lo contratos sólo producen efectos entre las partes que los celebran y sus herederos, salvo en cuanto a éstos, si se trata de derechos y obligaciones no transmisibles. Sin embargo, hay casos en los cuales los alcances del convenio arbitral se extienden a partes que no lo celebraron. Tal es el caso del arbitraje estatutario, el mismo que es susceptible de incorporarse a cualquier tipo de persona jurídica que contenga un estatuto. Vale precisar que el arbitraje estatutario, además, deberá ser interpretado a la luz de la legislación laboral, por su eventual contradicción con dichas normas.

- El convenio arbitral estatutario, no sólo se extiende a quienes lo celebran, es decir, a los socios, titulares, asociados o fundadores de la persona jurídica, sino a una serie de personas más, como es el caso de directores, administradores, representantes y funcionarios que, formando parte de la persona jurídica, evidentemente, no han celebrado dicho convenio arbitral. Esta característica resulta 
importante, pues ella constituye una situación excepcional a la regla del artículo 1363 del Código Civil.

- En ese sentido, deviene en fundamental para que sus efectos se extiendan a terceros no suscriptores, la inscripción del estatuto social en los Registros Públicos; ello, en la medida de que sólo la publicidad hará que dicho convenio arbitral estatutario tenga efectos con respecto a los terceros no suscriptores que todavía no ostenten la calidad de socios, asociados, accionistas, directivos, admiradores o representantes; o para quienes se incorporen en cualquiera de dichas calidades en el futuro.

- Según el tipo de arbitraje que contempla el convenio arbitral, éste podrá ser de derecho o de conciencia; institucional o ad-hoc; uno en el que las partes podrán someter cualquier o determinada futura controversia a arbitraje y/o determinada controversia existente. Así pues, si al arbitraje resultara de aplicación la ley peruana, será claro que, en caso estemos en presencia de un arbitraje nacional y de derecho, los árbitros deberán ser abogados; en tanto si el arbitraje fuese de conciencia, tales árbitros podrán ser de profesiones u oficios diferentes.

- Cabe señalar que si se tratase de un arbitraje regulado por la Ley de Contrataciones del Estado y su Reglamento, a pesar de ser un arbitraje de derecho, los árbitros de parte podrán ser o no abogados, debiendo el presidente y el árbitro único tener la profesión de abogado, además contar con tres especialidades acreditadas en: (i) derecho administrativo, (ii) arbitraje, y (iii) contrataciones con el Estado.

- El arbitraje también podrá ser celebrado como cláusula contractual o como contrato independiente; podrá ser bilateral, plurilateral o unilateral; restringir sus efectos a quienes lo celebran o a terceros; formar parte de contratos de negociación previa, por adhesión o con cláusulas generales de contratación; institucional o ad-hoc; contemplar un plazo para la solución de la controversia, o no hacerlo; contemplar o no el número de árbitros; contemplar o no el idioma en que se desarrollará el proceso; contemplar o no la manera de elegir a los árbitros; y otros supuestos más.

- Toda nuestra legislación referida al arbitraje — desde el Código de Procedimientos Civiles de 1912-, ha establecido invariablemente que el convenio arbitral debe revestir formalidad escrita. Sin embargo, con el paso de los años, el concepto de tal formalidad se ha ido flexibilizando, de tal manera que, si bien la formalidad escrita permanece como regla, su contenido y alcances han variado sustancialmente, como 
puede ser apreciado del contenido del artículo 13 de la Ley de Arbitraje, desarrollado en el tercer capítulo de la presente investigación.

- En este sentido, cabe resaltar que la Ley de Arbitraje peruana se equivoca o, en todo caso, lleva a confusión, cuando señala, en el numeral 5 de su artículo 13, que el convenio arbitral se entenderá que consta por escrito en un intercambio de escritos de demanda y contestación. Consideramos que la norma debería referirse a la solicitud de arbitraje y contestación a dicha solicitud; toda vez que es en la solicitud de arbitraje, donde la futura parte demandante manifiesta su intención de resolver una determinada controversia a través del arbitraje, designando inclusive - al árbitro correspondiente. Así, en la contestación a la solicitud de arbitraje, la futura parte demandada, tendrá la oportunidad de negar u oponerse al arbitraje por inexistencia de convenio arbitral. Caso contrario, si la futura parte demandada, contestara la solicitud de arbitraje sin negar la existencia del acuerdo arbitral afirmado por su futura contraparte, se entenderá que el convenio arbitral existe y por escrito. Tómese nota, además, de que la Ley de Arbitraje, salvo acuerdo distinto entre las partes, establece que el arbitraje se inicia con la recepción de la solicitud para someter una controversia a arbitraje. 


\section{REFERENCIAS}

Aguilar Grieder, H. (2001). La extensión de la cláusula arbitral a los componentes de un grupo de sociedades en el arbitraje comercial internacional. La Coruña: Universidad de Santiago de Compostela.

Alsina, H (s.f.). Tratado teórico práctico de Derecho Procesal Civil y Comercial. Buenos Aires: Ediar E.S. Editores, tomo vii.

Barrios de Angelis, D. (1956). El juicio arbitral. «Biblioteca de Publicaciones Oficiales de la Facultad de Derecho y Ciencias Sociales» de la Universidad de Montevideo, Sección iii-xci.

Bernardo San José, A. (2002) Arbitraje y jurisdicción: incompatibilidad y vías de exclusión. Granada: s/e.

Cabanellas, G. (1989). Diccionario enciclopédico de derecho usual. Buenos Aires: Editorial Heliasta, 1989, tomo 11.

Cantuarias Salaverry, F. (2007) Arbitraje comercial y de las inversiones. Lima: Universidad Peruana de Ciencias Aplicadas.

Castillo Freyre, M. y Vásquez Kunze, R. (2006). Arbitraje. El juicio privado: la verdadera reforma de la justicia. «Biblioteca de Arbitraje». Lima: Estudio Mario Castillo Freyre-Palestra Editores, vol. 1.

Castro Zapata, L. (2008). El convenio arbitral vs. el acta de instalación (o en qué ocasiones puede modificarse lo pactado en el convenio arbitral). Ponencia pronunciada en el Segundo Congreso Internacional de Arbitraje de la Pontificia Universidad Católica del Perú. Lima: Estudio Mario Castillo Freyre-Palestra Editores, volumen 6.

Charry Uribe, L. (1988). Arbitraje mercantil internacional. Bogotá: Pontificia Universidad Javeriana.

Cruzado Balcázar, A. (1989). Diccionario de sinónimos jurídicos. Limas: Editorial San Marcos.

De la Puente y Lavalle, M. (2002). El contrato en general. Lima: Palestra.

De la Puente y Lavalle, M. (2002) «La convención y el contrato». En Advocatus. Revista editada por alumnos de la Facultad de Derecho de la Universidad de Lima,

Enciclopedia Jurídica Omeba. (1962) Buenos Aires: Editorial Bibliográfica. 
García-Calderón Moreyra, G. (2004). El arbitraje internacional: En la sección segunda de la Ley n. ${ }^{\circ}$ 26572. Lima: Cesosami,

Guasp, Jaime. El arbitraje en el Derecho español. Barcelona: Editorial Bosch, 1956.

Larroumet, C. (2005). «A propósito de la naturaleza contractual del acuerdo de arbitraje en materia internacional y de su autonomía». En El contrato de arbitraje. Bogotá: Legis y la Universidad del Rosario.

León Barandiarán, J. (1997). Acto jurídico. Lima: Gaceta Jurídica.

Lohmann Luca de Tena, J. G. (1988). El Arbitraje. En Biblioteca Para leer el Código Civil. Lima: Fondo Editorial de la Pontificia Universidad Católica del Perú. 2. ${ }^{\text {a }}$ ed., vol. v.

Montoya Alberti, U. (1988). El arbitraje comercial. Lima: Cultural Cuzco, 1988.

Ogayar y Ayllón, T. (1977). El contrato de compromiso y la institución arbitral. Madrid: Editorial Revista de Derecho Privado.

Pucci, A. (1977). Arbitraje en los países del Mercosur. Buenos Aires: Ad Hoc, 1997.

Sánchez Andrade, . P. del C. (1990). El arbitramento en Colombia. Bogotá: Pontificia Universidad Javeriana, p. 51.

Taboada Córdova, L. (2002) Acto jurídico, negocio jurídico y contrato. Lima: Grijley, 2002.

Vidal Ramírez, F. (2007). El acto jurídico. Lima: Gaceta Jurídica, 7. a ed. 